\title{
Tomasz Kucharski
}

\section{Przepisy porządkowe na zjazdach elekcyjnych w latach 1587-1674}

Wolne elekcje królów polskich są niewątpliwie jednym z najbardziej fascynujących i niezwykłych zjawisk życia społecznego, politycznego i prawno-instytucjonalnego nowożytnej Europy. Już w okresie od XVI do XVIII w. były one przedmiotem zainteresowań opinii publicznej zarówno w Polsce, jak i za granicą. Do dziś powstają na ich temat książki i artykuły, wychodzące spod pióra wybitnych badaczy, wyrażające pragnienie opisania i zrozumienia tej oryginalnej procedury obsadzania tronu ${ }^{1}$. Juliusz Bardach trafnie ocenił, że pro-

1 Nie sposób w tym miejscu odesłać do całej literatury dotyczącej genezy, przebiegu i znaczenia wolnych elekcji (oraz szerzej - bezkrólewi) w Polsce w latach 1573-1764. Wskażemy zatem tylko egzemplifikacyjny katalog najważniejszych i najbardziej wartościowych pozycji: M. Chmielewska, Sejm elekcyjny Michała Korybuta Wiśniowieckiego 1669 r., Warszawa 2006, passim; E. Dubas-Urwanowicz, Koronne zjazdy szlacheckie $w$ dwóch pierwszych bezkrólewiach po śmierci Zygmunta Augusta, Białystok 1998, passim; eadem, Bezkrólewie - czas integracji czy podziałów?, Przegląd Historyczny 1994, z. 1, s. 35-43; J. Dzięgielewski, Sejmy elekcyjne, elektorzy, Pułtusk 2003, passim; S. Gruszecki, Walka o władzę w Rzeczypospolitej Polskiej po wygaśnięciu dynastii Jagiellonów (1572-1573), Warszawa 1969, passim; W. Kaczorowski, Sejmy konwokacyjny i elekcyjny $w$ okresie bezkrólewia 1632 r., Opole 1986, passim; H. Olszewski, Sejm $w$ dawnej Rzeczypospolitej, ustrój i idee, t. I, Poznań 2002, s. 224-241; S. Płaza, Próby reform ustrojowych z czasów pierwszego bezkrólewia 1572-1574, Kraków 1969; idem, Wielkie bezkrólewia, Kraków 1988; passim; P. Skwarczyński, Pierwsze trzy wolne elekcje viritim 1573-1587 (zagadnienia wybrane), Teki Historyczne 1959, t. 10, s. 119-154, W. Sobociński, Pakta Konwenta, Kraków 1939, passim; A. Sucheni-Grabowska, Sejm w latach 1540-1587, [w:] 
blem wolnych elekcji królów jest zagadnieniem węzłowym dla zrozumienia całej konstrukcji ustrojowej Rzeczypospolitej szlacheckiej, i to zarówno w wymiarze prawnym, jak i politycznym czy społecznym $^{2}$. Zagadnienie to, co oczywiste, wykazuje znaczący stopień skomplikowania, dlatego też współczesnego stanu badań nad nim nie można uznać za zadowalający, mimo niewątpliwych i licznych dokonań polskiej historiografii na tym polu. Naszym zdaniem podstawowy mankament dotychczasowych badań nad bezkrólewiami i ich kulminacyjnymi elementami - zjazdami elekcyjnymi, tkwi $z$ jednej strony w nadmiernej koncentracji na sprawach ogólnych, mówiąc ściślej na dokonywaniu generalizacji i syntez, bez uprzedniego żmudnego i wnikliwego przeanalizowania konkretnych problemów i zagadnień szczegółowych, a z drugiej w rozpatrywaniu poszczególnych bezkrólewi w odseparowaniu od siebie. Naszym gorącym pragnieniem jest, by odpowiedzią na te niedomagania stał się, chociaż w drobnym stopniu, niniejszy szkic, poświęcony szczegółowej kwestii porządkowych przepisów elekcyjnych. Zagadnienie to pragniemy ukazać przekrojowo w perspektywie 5 zjazdów elekcyjnych $z$ lat $1587-1674^{3}$. Takie ujęcie wydaje się rozwiązaniem

Historia sejmu polskiego, t. I: Do schyłku szlacheckiej Rzeczypospolitej, red. J. Michalski, Warszawa 1984, s. 200-216; W. Zakrzewski, Po ucieczce Henryka. Dzieje bezkrólewia 1574-1575, Kraków 1878. Warto w tym miejscu nadmienić także o świeżych pracach: A. Pieńkowska, Zjazdy i sejmy z okresu bezkrólewia po śmierci Stefana Batorego, Pułtusk 2010; A. Skrzypietz, Francuskie zabiegi o koronę polska po śmierci Jana III Sobieskiego, Katowice 2009.

2 J. Bardach, Sejm doby oligarchii, Kwartalnik Historyczny 1967, z. 2, s. 372 .

3 Zakres chronologiczny pracy został zakrojony w taki, a nie inny sposób ze względu na niewielką objętość szkicu. Przepisy porządkowe na pierwszej elekcji były znacząco uboższe treściowo, zawierały jedynie 10 norm o wymiarze stricte prawnokarnym. Kolejna elekcja, „podwójna”, dokonywana w niepewnej sytuacji prawnej po detronizacji Henryka Walezego, nie pozostawia nam ciekawego i istotnego materiału. Obie te elekcje w rozważaniach pominiemy. Uwzględniamy natomiast trzecią elekcję, mimo iż wybór był „podwójny”, a zjazd elekcyjny nie pozostawił po sobie w zasadzie żadnego dorobku legislacyjnego, uczynimy tak tylko ze względy na fakt, że doświadczenia roku 1587 wpłynęły wydatnie na ostateczne ukształtowanie przepisów porządkowych. Pomijamy natomiast całkowicie obie elekcje 
optymalnym zarówno dla tradycyjnego badacza dziejów (któremu pozwolić powinno na uchwycenie pewnych stałych dla większości zjazdów elekcyjnych problemów organizacyjnych, a także na skonfrontowanie zastosowanych wobec nich rozwiązań z praktyką, w różnorodnych realiach społecznych i politycznych), jak również historyka prawa (któremu umożliwić może dostrzeżenie prawidłowości w charakterze i ewolucji regulacji prawnych).

Na początku szkicu konieczne wydaje się dokonanie eksplikacji pewnej dystynkcji terminologicznej odnoszącej się do „porządku elekcyjnego", terminem tym określano bowiem dwa zjawiska, o odmiennym charakterze i specyfice. W pierwszym znaczeniu rozumiano pod nim formalne regulacje dotyczące procedury odbycia zjazdu elekcyjnego: od jego początku, którego termin oznaczano na sejmach konwokacyjnych, aż do ogłoszenia wyboru i zaprzysiężenia paktów konwentów, czy nawet koronacji ${ }^{4}$. Procedury te odnosiły się przy tym zarówno do obrad w czasie sejmu elekcyjnego, jak i przeprowadzania wyboru monarchy. Opierały się one na normach prawa zwyczajowego, nie zostały bowiem skodyfikowane, mimo licznych prób i przedkładania od schyłkowych lat rządów Zygmunta Augusta projektów ustaw tytułowanych Modus eligendi Regis Poloniae ${ }^{5}$.

saskie, obie elekcje Leszczyńskiego oraz wybór Stanisława Augusta Poniatowskiego, ponieważ miały burzliwy charakter, przebiegały przy ingerencji państw obcych i nie przedstawiają dla naszych rozważań żadnej wartości, mimo iż przepisy porządkowe na nich uchwalano.

4 Por. P. Skwarczyński, op.cit., s. 122 i n.

5 Niestety, projekty uregulowania trybu przeprowadzania zjazdów elekcyjnych, obrad sejmu elekcyjnego i wyboru króla nie cieszą się, jak dotąd, szczególnym zainteresowaniem wydawniczym. Wydaje nam się, że warto byłoby opublikować takie projekty, szczególnie te najistotniejsze, autorstwa J. Zamoyskiego czy S. Karnkowskiego, które rzucają pewne światło na poglądy opinii publicznej i kulturę prawną ówczesnej szlachty w odniesieniu do najważniejszego aktu jej zwierzchnictwa w Rzeczypospolitej przedrozbiorowej. Pewne anonimowe, mniej istotne projekty ustalenia procedury przeprowadzenia zjazdu elekcyjnego doczekały się publikacji, por. Senator Anonim, Traktat de interregno z r. 1587, [w:] Sześć broszur politycznych z XVI i początku XVII stulecia, wyd. B. Ulanowski, Kraków 
Drugim znaczeniem frazy „porządek elekcyjny” było sprawne i bezpieczne przeprowadzenie zjazdu elekcyjnego, odnoszące się nie tylko do technicznych aspektów przeprowadzenia obrad sejmowych i wyboru monarchy, ale także do kwestii zaplecza logistycznego i materialnego całego przedsięwzięcia. Należy w tym miejscu zaznaczyć, że postrzeganie porządku i bezpieczeństwa wewnętrznego państwa, zwłaszcza w okresie bezkrólewia, obejmowało nie tylko zagwarantowanie nietykalności osobistej i majątkowej szlachty, ale także ochronę nienaruszalnych praw politycznych narodu szlacheckiego, z prawem wyboru monarchy i przywilejami fiskalnymi na czele $^{6}$. Dla realizacji i zapewnienia tak rozumianego porządku na zjazdach elekcyjnych uchwalano specyficzne przepisy prawne, których celem było zapewnienie bezpieczeństwa i relatywnego komfortu ich uczestnikom oraz uczciwe i zgodne $z$,demokratycznymi” standardami przeprowadzenie obrad sejmu elekcyjnego, a także wybór monarchy. Właśnie to rozumienie terminu „porządku elekcji” będzie przedmiotem niniejszego artykułu ${ }^{7}$.

Zasadniczym celem naszych rozważań będzie próba przedstawienia prawniczej analizy znacznej części przepisów o bezpieczeństwie i porządku na zjazdach elekcyjnych w kontekście wymogów orga-

1921; Alia forma de interregno et modo eligendi regis, [w:] Reforma elekcji czy naprawa Rzeczypospolitej (wybór źródeł 1630-32), wyd. W. Konopczyński, Kraków 1949.

6 Wynikało to $\mathrm{z}$ faktu, że głównym, bezpośrednim zadaniem partykularnych konfederacji szlacheckich w czasie pierwszych bezkrólewi było zwłaszcza zapewnienie sądownictwa i służb porządkowych, ale pośrednio, w sensie politycznym, były one manifestacją podmiotowości politycznej szlachty, obawiającej się wykorzystania bezkrólewia przez senatorów do ograniczenia uprawnień średniej i drobnej szlachty, por. E. Dubas-Urwanowicz, Koronne zjazdy, s. 11-87.

7 Opis zawartości istotniejszych przepisów porządkowych, niestety bez wyczerpującej analizy prawnej i głębszej refleksji nad ich kształtem i znaczeniem, odnajdujemy w pracy P. Skwarczyńskiego, op.cit., s. 121 i n., a także w obu monografiach sejmów elekcyjnych, pióra M. Chmielewskiej, Sejm elekcyjny, s. 158-166 oraz W. Kaczorowskiego, op.cit., s. 225-232. Pewne światło na omawiane zagadnienie rzuca mały szkic pióra M. Chmielewskiej, Z życia codziennego podczas elekcji Michała Korybuta Wiśniowieckiego w 1669 roku, Sobótka 1996, z. 1-3, s. 118-125. 
nizacyjnych, niezwykle przecież skomplikowanych logistycznie przedsięwzięć, jakimi niewątpliwie były wielotysięczne zjazdy pokaźniej części najliczniejszego w Europie stanu uprzywilejowanego ${ }^{8}$. Dla spełnienia swoich politycznych celów zjazdy musiały przecież być przygotowane w taki sposób, aby umożliwić prowadzenie obrad publicznych i wybranie monarchy zgodnie $z$ prawem oraz standardami kultury politycznej panującymi w Rzeczypospolitej.

Normy porządkowe dotyczące bezpieczeństwa zjazdów elekcyjnych zawarte były zawsze w dwu specyficznych dla Polskich bezkrólewi aktach prawnych ${ }^{9}$. Część zamieszczano w Akcie Konfederacji Generalnej Warszawskiej uchwalanym na sejmie konwokacyjnym ${ }^{10}$, pozostałe przygotowywano już na samym sejmie elekcyjnym i for-

8 Naturalnie większość relacji źródłowych operuje przesadzonymi wartościami, określając liczbę uczestników elekcji (np. Wilhelm Beauplan szacuje liczbę szlachty na elekcji Władysława IV na aż 80 000!, por. W. Beauplan, Opisanie Ukrainy tudzież rzeki Borystenes Niepr bądź Dniepr pospolicie zwanej od Kijowa poczquwszy aż do morza $w$ które ona uchodzi, [w:] Eryka Lassoty $i$ Wilhelma Beauplana opisy Ukrainy, red. Z. Wójcik, Warszawa 1972, s. 163).

W literaturze przedmiotu odnajdujemy rzetelne badania nad liczebnością zjazdów elekcyjnych, por. J. Dzięgielewski, op.cit., s. 67-78; P. Skwarczyński, op.cit., s. 132-135.

9 W zasadzie należałoby mówić o trzech źródłach elekcyjnego prawa porządkowego, albowiem w niebudzących kontrowersji technicznych sprawach organizacyjnych prymasom przysługiwało uprawnienie do wydawania specjalnych uniwersałów.

10 Por. Konfederacja generalna warszawska roku 1587, Volumina Legum, wyd. J. Ohryzko, Petersburg 1858-1859 (dalej: VL), t. II, s. 226-233, fol. 1054-1068; Konfederacja generalna omnium Ordinum Regni et M(agni) D(ucatus) Lit(uaniae) na konwokacyi głównej warszawskiej uchwalona, roku P(ańskiego) 1632 dnia 16 lipca, VL, t. III, s. 345-353, fol. 753-741; Konfederacja generalna omnium Ordinum Regni et. M(agni) D(ucatus) Lit(uaniae) na konwokacyi głównej warszawskiej uchwalona, r(oku) Pańskiego 1648 dnia 16 miesiacca lipca, VL, t. III, s. 74-87, fol. 148-180; Konfederacja generalna omnium Ordinum Regni et. M(agni) D(ucatus) Lit(uaniae) na konwokacyi głównej warszawskiej uchwalona, roku Pańskiego 1668 dnia 5 miesiaca nowembra, VL, t. IV, s. 482-501, fol. 1025-1068; Konfederacja generalna omnium Ordinum Regni et. Magni Ducatus Lituaniae na konwokacyi głównej warszawskiej uchwalona, r(oku) P(ańskiego) 1674 dnia 15 miesiaca stycznia, VL, t. V, s. 110-132, fol. 199-249. 
mowano $z$ nich uchwałę, zwaną Porządkiem elekcyjnym ${ }^{11}$. Szczególnie istotne było to drugie źródło, którego przygotowanie i uchwalenie miało być jedną z pierwszych czynności podejmowanych przez koło poselskie sejmu elekcyjnego - powinno było nastąpić zaraz po wyborze marszałka sejmu elekcyjnego oraz sędziów sądu elekcyjnego zwanego Kapturem Generalnym. Należy wszakże podkreślić, że brak skodyfikowanej procedury przeprowadzania sejmów elekcyjnych jak również niesubordynacja posłów powodowały, że uchwalenie tego aktu zaraz na początku sejmu stawało się koncepcją czysto teoretyczną, tyleż pożądaną, co eskapistyczną. I tak w omawianym przez nas okresie historycznym na sejmie elekcyjnym 1587 r. przepisów porządkowych nie udało się uchwalić w ogóle (znamy doskonale dramatyczny przebieg tego zgromadzenia zakończonego dwiema alternatywnymi elekcjami, rozstrzygniętymi dopiero bitwą pod Byczyną ${ }^{12}$ ), na elekcji 1632 r. przepisy porząd-

11 Por. Porzadek na seymie walnym elekcyi, między Warszawa a Wola opisane artykuły do samego tylko aktu elekcyi należace, uchwalony y postanowiony roku Pańskiego 1632 dnia 27 września, VL, t. III, s. 358-360, fol. 753-758; Porzacdek na seymie walnym elekcyi, między Warszawa a Wola opisane artykuły do samego tylko aktu elekcyi należace, uchwalony y postanowiony roku Pańskiego 1648 dnia 6 października, VL, t. IV, s. 87-90, fol. 180-186; Porządek na seymie walnym elekcyi, między Warszawa a Wola opisane artykuły do samego tylko aktu elekcyi należace, uchwalony y postanowiony roku Pańskiego 1669, dnia 2 miesiaca maia, VL, t. V, s. 5-8, fol. 1-7; Porządek na seymie walnym elekcyi, między Warszawą a Wolą opisane artykuły do samego tylko aktu elekcyi należące, uchwalony y postanowiony r(oku) P(ańskiego) 1674 dnia 20 miesiaca kwietnia, VL, t. V, s. 132-135, fol. 249-255.

Porządek elekcyjny wydawano na mocy normy upoważniającej do jego uchwalenia, zawartej w konfederacji generalnej: „A co się tycze porządku, bespieczeństwa y sprawiedliwości in reditu ab Electione, tedy tamże na Elekcyi sposób o tym ma bydź namówiony", VL t. III, s. 348, fol. 729; t. IV, s. 78, fol. 156; s. 487, fol. 1035; t. V, s. 115, fol. 208.

12 Burzliwy i bezowocny przebieg obrad zjazdu elekcyjnego 1587 r. zarówno w kole nazwanym prokonwokacyjnym, jak i antykonwokacyjnym obrazują relacje z obrad, por. O elekcyi króla JMci Zygmunta III, Proces elekcyi królewicza szwedzkiego Zygmunta, [w:] Dyaryusze sejmowe z r. 1587. Sejm konwokacyjny i elekcyjny, wyd. A. Sokołowski, Scriptores Rerum Polonicarum, t. XI, Kraków 1887, s. 57-158, 159-218; J. Bielski, 
kowe udało się uchwalić dopiero po upływie $11 \mathrm{dni}^{13}$, na elekcji 1669 r. po upływie 18 dni $^{14}$. Powstał w związku z tym skomplikowany problem prawny, mianowicie jak traktować ewidentne wykroczenia przeciwko bezpieczeństwu elekcyjnemu dokonane przed uchwaleniem przepisów. Na sejmie 1632 r. dyskutowano nawet nad tym, by przepisom porządkowym nadać wsteczną moc obowiązującą, łamiąc fundamentalną, znaną już od starożytności zasadę lex retro non agit, na co ostatecznie się nie zgodzono ${ }^{15}$. Należy wszakże

Dalszy ciag kroniki polskiej zawierającej dzieje od 1587 do 1598 r., wyd. F.M. Sobieszczeński, Warszawa 1851, s. 9-69; R. Heidenstein, Dzieje Polski od śmierci Zygmunta Augusta do roku 1594, t. II, tłum. M. Gliszczyński, Petersburg 1857, s. 222-248. W literaturze przedmiotu cenną analizę stanowi świeże opracowanie A. Pieńkowskiej, op.cit., passim.

13 Dnia 8 października 1632 r. osiągnięto konsensus w najbardziej kontrowersyjnym przepisie dotyczącym monety i ostatecznie opublikowano cały akt Porządku elekcyjnego, por. A.S. Radziwiłł, Pamiętnik o dziejach $w$ Polsce, przetłum. A. Przyboś i R. Żelewski, Warszawa 1980, t. I, s. 151-153.

14 Por. M. Chmielewska, $Z$ życia codziennego, s. 120. Autor najpoważniejszego diariusza tego sejmu elekcyjnego J.A. Chrapowicki nie wspomina o uchwaleniu przepisów porządkowych, ale informuje pod datą 20 maja 1669 r. o fiasku w dyskusji nad desygnacją deputatów do Kaptura Głównego. Brak zainteresowania uchwaleniem Porządku ma zapewne związek z powszedniością takowego opóźnienia w praktyce ustrojowej Rzeczypospolitej oraz faktem powtórzenia tej regulacji, w zasadzie dosłownym $z$ elekcji Jana Kazimierza, por. J.A. Chrapowicki, Diariusz, część druga: lata 1665-1669, oprac. A. Rachuba i T. Wasilewski, Warszawa 1988, s. 483 i n.

15 Albrycht Stanisław Radziwiłł tak relacjonuje te wydarzenia z 5 października 1632 r.: „Kiedy doszli [przy czytaniu artykułów uchwały o porządku - przyp. TK] do tego punktu, by nie przyjeżdżali na elekcję zbrojnie i z działami, książę [kasztelan wileński i hetman polny litewski Krzysztof - TK] Radziwiłł oznajmił, że do żadnej sprawy nie przystąpi, póki i ci co już przybyli z bronią, jak i ci co przybędą, nie zostaną podobnym rygorem objęci. Dwie godziny ciągnięto tę sprawę; jedni bowiem sądzili, że prawo to ma mieć moc chwili jego ogłoszenia, inni że od początku elekcji. Ustąpił w końcu książę Radziwiłł przed powagą i prośbą prymasa [...]”, A.S. Radziwiłł, op.cit., s. 148. W. Kaczorowski interpretuje tę sprawę inaczej, twierdząc, że punkt ten został wcześniej zatwierdzony na konwokacji i dlatego ks. Radziwiłł domagał się respektowania prawa już obowiązującego, por. W. Kaczorowski, op.cit., s. 226. Pogląd ów jest niestety trudny do zweryfikowania. Regulacja dotycząca przybywania na zjazd elekcyjny zbrojnie i $z$ cudzoziemcami obecna jest $\mathrm{w}$ tekstach konfederacji generalnych 
podkreślić, że oficjalnej publikacji Porzadku dokonywano $\mathrm{z}$ datą wsteczną - wyznaczaną początkiem elekcji, co może sugerować stosowanie tejże ustawy w pewnym sensie $z$ mocą wsteczną. Co istotne, ustawa o porządku elekcyjnym uległa $z$ biegiem kolejnych bezkrólewi petryfikacji w swej zasadniczej treści, trudno więc było szermować podstawowym argumentem przeciw retroaktywności niepewnością stanu prawnego.

Przyjętą w powyżej wskazany sposób uchwałę umieszczano w Voluminach Legum zaraz po arendze sejmu elekcyjnego, a przed ewentualnymi egzorbitancjami elekcyjnymi, paktami, konwentami

(1587 r.: „Cudzoziemców żadnych, y ludzi wszelakich obcych, aby ich żaden nie śmiał na Elekcyą prowadzić, ani z nimi przyieżdżać, ani ich przy sobie mieć y chować.Ani z działami y wszelaką strzelbą przyieżdżać, sub poena in confoederatione expressa [...] obiecuiemy to y przyrzekamy sobie pod wiarą y czcią naszą takowego każdego [...] iako nieprzyiaciela oyczyzny naszey mieć [...] y przeciw (n)iemu na iego wieczną skazę powstać, y onego zdrowia maiętności y gardłą pozbawić”, VL, t. II, s. 231, fol. 1063; w tekstach późniejszych: „Z strony przyieżdżania na Elekcyą reassumuiemy in toto artykuł z Konfederacyi Generalney Warszawskiey, roku 1587 o nieprzyieżdżaniu z cudzoziemcami y z działami”, VL, t. III, s. 347, fol. 729; t. IV, s. 77, fol. 156; s. 486-487, fol. 1034; t. V, s. 114, fol. 207 ). Została zawarta także w tekście Porząlku elekcyjnego, z tzw. objaśnieniem, czyli zestawem norm wykonawczych, ew. zawierających autentyczną wykładnię „stoiąc przy przeszłey Konfederacyi, punkt ex volumine legum, anni 1587 o nieprzyieżdżaniu z cudzoziemcami y działami, w niey reassumowany, tak obiaśniamy: że pułków, rot, z cudzoziemców cujuscunque nationis, tak konnych iako y pieszych, tudzież dział, nie ma nikt bliżey trzech mil pod Warszawę, ani iawnie podmykać, ani taiemnie intra dictum spatium okkultować: a ktoby inaczey uczynił, ten ex delatione cujusvis ad instantiam Instygatora Koronnego, ieśli Koronnym, abo W.K. L. ieśli Litewskim obywatelem będzie, ma bydź przed teraźnieysze compositum judicium pozwany”, VL, t. III, s. 358, fol. 754; t. IV, s. 87-88, fol. 181; t. V, s. 5, fol. 1-2; s. 132-133, fol. 250). Niewątpliwie jednak opinia wyrażona przez ks. Radziwiłła na sejmie elekcyjnym 1632 dotyczyła objęcia „nowym rygorem”, czyli szczegółowymi normami „objaśnienia”, osób, które przybyły na zjazd elekcyjny przed uchwaleniem przepisów wykonawczych. Autor cytowanego diariusza, będący przecież kanclerzem wielkim litewskim, wyraźnie wspomina, że dyskusja dotyczyła momentu uzyskania mocy obowiązującej przez pomieniony przepis. Problem ten wymaga oddzielnego potraktowania, na co niestety nie pozwala skromny rozmiar szkicu niniejszego. 
i innymi uchwałami tego zgromadzenia. Akt był podpisywany przez prymasa, marszałków wielkich: koronnego i litewskiego, marszałka izby poselskiej oraz marszałków nadwornych: koronnego i litewskiego.

Elekcyjne przepisy porządkowe podzielić można, w aspekcie przedmiotowym, w zasadzie na dwie kategorie:

1) przepisy proceduralne, mające na celu zapewnienie odpowiedniego standardu stosowania przepisów materialnych,

2) przepisy materialne, wśród których wymienić można dwa podtypy:

a) normy karne,

b) specyficzne obowiązki o charakterze quasi-administracyjnym (które pozwoliliśmy sobie nazwać przepisami sensu stricto porządkowymi) ${ }^{16}$.

Dodać należy, że zarówno przepisy karne, jak i porządkowe sensu stricto można pod względem ich zasięgu przestrzennego podzielić na dwie kategorie przepisów:

1) dotyczące okopu i pola elekcyjnego (miały zagwarantować bezpieczne i legalne obrady oraz głosowanie),

2) dotyczące bezpieczeństwa zjazdu w ogóle (miały zapewnić porządek w Warszawie i okolicach w trakcie sejmu elekcyjnego).

16 By klarownie omówić istotę elekcyjnych przepisów porządkowych sensu stricto, pozwolimy sobie na zaprezentowanie pewnej, na pierwszy rzut oka może nazbyt odważnej, ale w naszym najgłębszym przekonaniu trafnej paranteli ze współczesnym systemem prawnym. Przepisy te przypominały w zasadzie współczesne normy z zakresu ochrony bezpieczeństwa imprez masowych. Mimo iż cel obu typów zjazdów jest diametralnie odmienny (szlachta zgromadzona na polu elekcyjnym stawiała sobie za zadanie prowadzenie obrad w sprawach publicznych oraz wybór monarchy, zjazdy określane współcześnie jako imprezy masowe służą celom stricte rozrywkowym), to pod względem organizacyjnym i logistycznym przedsięwzięcia te wykazują liczne podobieństwa. Uczestnikom trzeba przecież zapewnić nocleg, należy rozwiązać kwestie wyjść ewakuacyjnych i dróg, urządzeń sanitarnych, ochrony przeciwpożarowej oraz aprowizacji (ze szczególnym uwzględnieniem reglamentacji w handlu napojami alkoholowymi i artykułami spożywczymi), a także wprowadzić rozwiązania odnoszące się do środków płatniczych. 
Co oczywiste, materialne elekcyjne przepisy porządkowe należy także rozpatrywać, biorąc za punkt wyjścia kryterium przedmiotowe, które będzie nam szczególnie przydatne w dalszych rozważaniach. Możemy tu wyodrębnić przepisy:

1) dotyczące legalnego i bezpiecznego przeprowadzenia obrad i aktu elekcyjnego,

2) dotyczące przydzielania i najmowania gospod,

3) dotyczące bezpiecznej przeprawy przez most,

4) dotyczące obrotu towarowego,

5) przeciwpożarowe,

6) dotyczące szeroko pojętego porządku publicznego w czasie zjazdu.

Przy bliższym przyjrzeniu się treści omawianych przepisów konstatacje powyższe wydają się oczywiste, ale uważaliśmy za nieodzowne przedstawienie tych drobnych uwag klasyfikacyjnych ze względu na częste opisywanie omawianych przepisów niezwykle wybiórczo, z położeniem głównego nacisku na ich aspekt prawnokarny i represyjny charakter. Podziały, które zarysowaliśmy, znacząco ułatwią rozpatrywanie przepisów porządkowych w sposób usystematyzowany, ukazujący ich różnorodność i polimorficzne skutki dla prawidłowego funkcjonowania zjazdów elekcyjnych.

\section{Przepisy proceduralne}

W tym miejscu pragniemy poświęcić parę słów proceduralnym elekcyjnym przepisom porządkowym. Obejmowały one zarówno uprawnienia i obowiązki odpowiednich służb porządkowych, jak również organizację i tryb rozpatrywania przez sąd Kaptura Generalnego, spraw z zakresu naruszania porządkowych norm materialnych ${ }^{17}$. Jeśli chodzi o pierwszą kwestię, tj. normy dotyczące

17 W tym miejscu warto podkreślić, że kognicja Kaptura nie rozciągała się poza okres obradowania sejmu elekcyjnego i nie obejmowała spraw związanych $z$ bezpieczeństwem osób powracających $z$ elekcji, por. spór dotyczące określenia sądu właściwego dla tych spraw w relacji A.S. Radziwiłła, op.cit., s. $154,160$. 
służb porządkowych, regulacja była nadzwyczaj lapidarna, ustanawiała tylko ogólną zasadę, że odpowiedzialnymi za zapewnienie porządku i bezpieczeństwa zjazdu elekcyjnego mieli być na terenie Warszawy i w promieniu mniej więcej $30 \mathrm{~km}$ od niej ${ }^{18}$ mieli być „urząd Ichmciów PP. Marszałków oboyga narodów; także słudzy Urzędu Ichmciów”. Główną rolę odgrywał tu, ze względu na kryterium geograficzne, marszałek wielki koronny, a wspierała go stuosobowa straż ${ }^{19}$. Nie sprecyzowano żadnego katalogu uprawnień im przysługujących, na podstawie dostępnego materiału źródłowego można jedynie powiedzieć, że mogli stosować środki przymusu bezpośredniego, tzn. uderzać pałką lub laską, ale tylko plebejuszy, np. w sytuacji gdyby buczeniem, gwizdaniem lub krzykami zakłócali audiencje posłów cudzoziemskich ${ }^{20}$. Należy podkreślić, że liczba

18 Przepisy porządkowe stanowiły o trzech milach od Warszawy, biorąc pod uwagę fakt, że mała polska mila wynosiła $6250 \mathrm{~m}$, to promień wynosiłby $18750 \mathrm{~m}$; analizując dużą milę polską, wynoszącą $7810 \mathrm{~m}$, promień wynosiłby natomiast $23700 \mathrm{~m}$. Z praktyki wynika jednak, o czym będziemy mówić przy sprawie zapewnienia miejsc noclegowych w okolicach Warszawy, że obszar jurysdykcji nie mógł być jasno ustalony i mógł znacząco przekraczać nawet $30 \mathrm{~km}$, stąd nasza orientacyjna informacja sytuująca granicę jurysdykcji służb marszałkowskich i Kaptura Generalnego na $30 \mathrm{~km}$ od stolicy.

19 Za czasów saskich skład tzw. milicji marszałkowskiej powiększono do 150 osób, por. Z. Góralski, Encyklopedia urzędów i godności w dawnej Polsce, Warszawa 2000, s. 82.

20 "Chłopięta, pacholikowie, y inni lekkie osoby, aby się na ten plac y mieysce, gdzie Panowie Rady y rycerstwo zasiadać będą nie cisnęli: y na każdym inszym mieyscu, aby się spokoynie bez wszelkiego wołania, huczenia, świstania, skromnie zachowywali; a zwłaszcza przy słuchaniu Posłów postronnych, którym tak samym iako y sługom ich, przystoyną uczciwość czynić y oddawać maią: a ktoby w tey mierze wystąpił, a laską abo korbaczem mu się dostało, aby to pana iego nie obrażało", VL t. III, s. 359, fol. 756; t. IV s. 89 , fol. 183 ; t. V, s. 6 , fol. 4; s. 134 , fol. 252 . W tym miejscu warto zauważyć, że kwestii działalności drabów dotyczyły dwa porządkowe przepisy karne, świadczące o olbrzymim zainteresowaniu szlachty sprawami związanymi $z$ tzw. nadużyciem władzy publicznej, a przy tym chęć zagwarantowania maksymalnej skuteczności działania organów porządkowych. Otóż z jednej strony przewidziano sankcję za wykroczenie przez 
drabów była nazbyt niska jak na potrzeby tak licznych zjazdów, toteż patrzono przez palce na praktykę nielegalnego wspomagania się przez marszałków oddziałami prywatnymi w celu zaprowadzenia porządku w Warszawie i okolicach. Takie działania podejmował m.in. Jan Sobieski (będący, co istotne, także hetmanem wielkim koronnym) na sejmie elekcyjnym 1669 r., gdzie posiłkował się swoimi prywatnymi oddziałami piechoty ${ }^{21}$.

Większą, choć także niewystarczającą liczbę norm poświęcono kwestii postępowania sądowego przed elekcyjnym Kapturem Generalnym $^{22}$. Warto podkreślić, że powołanie tego sądu było rozwiązaniem kompromisowym, albowiem w pierwszych bezkrólewiach marszałkowie twierdzili, iż ich jurysdykcja $z$ czasu regnum nie wygasa, tylko zmienia swój charakter na skutek śmierci króla, i że w konsekwencji ochrona sejmu elekcyjnego, tak jak każdego innego, należy do ich wyłącznej kompetencji ${ }^{23}$. Szlachta natomiast

sługi marszałka poza zakres ich uprawnień („A gdzieby też który z sług Ichmość PP. Marszałków, albo Ichmciów PP. Deputatów, wykroczył: ma bydź od Ichmciów PP. Marszałków, y Ichmość PP. Deputatów sądzony, y pro qualitate delicti, pari, iako y drudzy deliquentes, poena ma bydź karany: w czym reassumuiemy Konfederacyą anno 1573”). Z drugiej strony „targnięcie się” jak to określono, na osobę sługi marszałka jako przestępstwo formalne (bezskutkowe) zagrożone miało być karą ucięcia dłoni. Uregulowano przy tym specyficzne obostrzenie kary przez następstwo, tzn. faktyczne zranienie członka marszałkowskiej straży miało być karane śmiercią (słudzy marszałka - TK), ,aby bezpieczeństwo mieli, tak deklaruiemy: ktoby się na którego $z$ sług Ichmciów in officio będącego targnął, albo uderzył, choć nie ranił, na ręce: a ktoby ranił, na gardle ma bydź karan”), VL, t. III, s. 360, fol. 758; t. IV, s. 90, fol. 185; t. V, s. 7, fol. 6; s. 135, fol. 255 .

21 M. Chmielewska, Z życia codziennego, s. 122.

22 Sąd ten nie cieszył się szczególnym zainteresowaniem. W literaturze przedmiotu odnajdujemy tylko uwagi ogólne, niewykorzystujące w pełni nawet materiału normatywnego, niezawierające także żadnych informacji odnoszących się do praktyki funkcjonowania sądu, ani w aspekcie organizacji, ani szczegółów postępowania, ani linii orzeczniczej, por. zwłaszcza świeże opracowanie A. Abramski, A. Huras, Sądy kapturowe (1572-1764). Studium $z$ dziejów sądownictwa i prawa sądowego podczas bezkrólewi $w$ Rzeczpospolitej Szlacheckiej, Sosnowiec 2010, s. 58-63.

23 Część literatury przedmiotu także wyraża przekonanie, że uprawnie- 
żądała powołania zupełnie nowego organu sądowego, w obawie przed wykorzystaniem przez marszałków (wywodzących się przecież z kręgów senatorskich) swych szerokich uprawnień do wpływania na wybór króla przez zastraszanie lub eliminowanie oponentów politycznych ${ }^{24}$. Ostatecznie ustalono, że powołany zostanie sąd mieszany (compositum judicium), w skład którego wejść mieli, oprócz 4 marszałków, 3 deputaci senatorscy oraz 12 deputatów poselskich (po $4 \mathrm{z}$ Wielkopolski, Małopolski i Litwy) ${ }^{25}$. Deputaci poselscy mieli być wybierani przez koło rycerskie; w praktyce zatwierdzano $\mathrm{z}$ reguły kandydatury zgłoszone przez marszałka izby poselskiej. Procedura ta była jednakże przedmiotem sporów i dyskusji w trakcie obrad koła poselskiego na elekcjach $1648 \mathrm{r}^{26}$,

nia marszałków nie wygasały w czasie interregnum, por. np. Z. Góralski, op.cit., s. 84. Potwierdza tę opinię świadectwo źródłowe, por. P. Piasecki, Kronika, Kraków 1870, s. 61.

24 O dyskusji dotyczącej uprawnień sądowniczych marszałka na elekcji oraz o innych sporach poselsko-senatorskich podczas pierwszego bezkrólewia, zob. S. Gruszecki, op.cit., passim.

25 „A ktoby lub w ciągnieniu, lub na mieyscu sub actu Electionis, civilem vel criminalem iniuriam komu uczynił, tedy na to ma bydź compositum judicium, to iest, trzey Deputaci z Senatu, cztery z Małey Polski, cztery z Wielkiey, cztery z W.X. Lit. od rycerstwa, którzy pierwszego dnia Electionis od wszystkich zgodnie obrani bydź [...] maią", VL t. III, s. 348, fol. 729; t. IV, s. 78, fol. 156; s. 487, fol. 1035; t. V, s. 114, fol. 208.

26 Uprawnienie marszałka do wskazywania kandydatur zostało tu uzasadnione sporami województw, których liczba znacząco przekraczała przecież liczbę deputatów: „Proponował Pan Marszałek, żeby przystąpili do obrania Sędziów generalnych kapturowych [...] poczęły być o to nie małe kontrowersje”, które uspokojono „dawszy tę racyą: „Nie może być tych Sędziów większy numerus, jeno jako prawo opisało [...]. Gdziebyście WMM Panowie jeden drugiemu nieustąpił, nie staną ci Sędziowie; gdyż z kilkunastu Województw, jeno czterej być mają. Aleć to od dawnych czasów [...] darował to zwyczaj Marszałkowi, żeby mianował, kogo mu Pan Bóg do serca poda”, Dyaryusz seymu elekcyjnego w r. 1648 dnia 6 Października poczętego a dnia 25 listopada skończonego, [w:] Jakuba Michałowskiego wojskiego lubelskiego a później kasztelana bieckiego księga pamiętnicza, wyd. Z. Helcel, Kraków 1864, s. 220-221. 
1669 r. ${ }^{27}$ oraz 1674 r. ${ }^{28}$ Nominacji deputatów senatorskich dokonywał prymas ${ }^{29}$.

Przebieg postępowania sądowego przed Kapturem Generalnym nie niósł za sobą zbyt wielu innowacji w porównaniu z postępowaniem przed sądem marszałkowskim oraz Trybunałem Koronnym. Proces wszczynało zawiadomienie o popełnieniu czynu zabronionego przepisami elekcyjnymi, dokonywane przez figurę procesową „delatora”, którym był, co do zasady, pokrzywdzony ${ }^{30}$. Zgodnie

27 Jan Antoni Chrapowicki (ostatecznie wybrany deputatem) pod datą 18 maja 1669 r. pozostawił notę następującą: „W kole $z$ strony deputatów do kapturu głównego traktowano. Jedni bronili authoritatem pana marszałka, żeby on podawał drudzy przy prawie stawali, żeby wszytcy obierali. Dawano media, żeby pan marszałek czytał przez prowincje, a której się nie będą podobali, żeby przez sufragia obierali, albo się żeby pan marszałek zniósł privatim cum provinciis i dopiero promulgował”, J.A. Chrapowicki, op.cit., s. 488-489. Pomijając kwestie polityczne (Chrapowicki zdecydowanie kładzie ten spór na karb rywalizacji poszczególnych fakcji), widać wyraźnie, że zgodnie z prawem uznawano metodę wyboru deputatów, ale pragmatyzm nakazywał mniejsze lub większe odstępstwa od owej zasady, czy to przez zakulisowe negocjacje, $z$ zachowaniem pewnych tylko elementów, albo nawet wyłącznie fikcji, demokratycznych wyborów.

28 W diariuszu tego sejmu odnajdujemy najbardziej zdecydowaną kontestację metody demokratycznej: „Pan Skolimowski z Podlaskiego Woiewództwa, zatrzymał nominatią Deputatów Koła Rycerskiego do tychże Sądów [tzn. Kaptura Generalnego - TK] napieraiąc się aby ich obierać per calculos: co że iest difficle et inusitantum, po kilku głosach suspersedował; y mianował J. MćPan Marszałek do pomienionych Sądów Deputatów dwunastu”, Diariusz seymu warszawskiego Electiey Jana III od dnia 20 kwietnia do dnia 9 czerwca 1674 r., wyd. F. Kluczycki, Kraków 1881, s. 45. Interesująca jest tu szczególnie ocena metody głosowania przez autora diariusza, który ocenia ją jako „trudną” (co zrozumiałe), ale także „niezwykłą”, co w świetle powyższych rozważań budzi wątpliwości i wynika chyba z politycznej proweniencji autora.

29 Por. G. Lengnich, Prawo pospolite Królestwa Polskiego, Kraków 1836, s. 52 .

30 „Gdzieby się w domach, tak w mieście iako y w miasteczkach, y na wsiach stanowisk, także w drodze iako y w ciągnieniu, gwałty excessy, y wszelakie krzywdy, komu działy: tedy ad delationem ukrzywdzonych, coram iuditio composito sprawować się każdy peremptoriae powinien będzie", VL t. III, s. 360, fol. 757; t. IV, s. 89, fol. 184-185; t. V, s. 7, fol. 5; s. 134-135, fol. 253-254. Sprawa ta wróciła jeszcze na forum obrad 
z wyraźnym zapisem przed Kapturem Generalnym miał się stawić bez wyjątku każdy wezwany, w roli świadka, a przede wszystkim oskarżonego $^{31}$. Zwłaszcza względem oskarżonych stosowano tu ciekawy środek subordynujący, mianowicie przy najpoważniejszych przestępstwach niestawiennictwo „do prawa” miało się kończyć automatycznym wyrokiem zaocznym orzekającym karę banicji najpoważniejszej sankcji karnej znanej feudalnemu prawu karnemu ${ }^{32}$. Warto podkreślić, że wyroki miały zapadać większością głosów, ustalono przy tym quorum, dopuszczając maksymalną liczbę dwu lub trzech nieobecnych deputatów, których absencja miała nie blokować pracy sądu i nie odbierać mu mocy wydawania prawomocnych orzeczeń ${ }^{33}$. Co ciekawe, stosowano znaną powszechnie współczesnym procedurom instytucję prawną wyłączenia

publicznych sejmu elekcyjnego $1632 \mathrm{r}$. w żądaniu szlacheckim odnowienia przysięgi marszałkowskiej. Marszałek koła rycerskiego, uzasadniając przed prymasem omawiany postulat, argumentował, że „pierwej [tj. w czasie regnum - TK] wykonywali swoje sądy tylko w najbliższej okolicy Warszawy, teraz zaś rozciągają swoją władzę na wiele mil; następnie nie ma żadnej wzmianki w ich przysiędze o nie wydawaniu tajemnic, o praktykach wśród stronnictw. Marszałek wielki koronny powiedział, że sądzi publicznie i żadnemu stronnictwu nie zwykł sprzyjać, lecz dla dobra pokoju, by sprawiedliwość na tym nie ucierpiała, gotów jest powtórzyć swą przysięgę", A.S. Radziwiłł, op.cit., s. 149. Por. też przyp. nr 23.

31 „O takowe y insze wszelakie, pod ten czas Elekcyi popełnione excessy, każdy wszelakiey kondycyi człowiek, ma się sprawować przed sądem Ichmciów PP. Marszałków, Ichmciów PP. Deputatów, oboyga narodów tanquam in recenti crimine, y judicatum pati”, VL t. III, s. 360, fol. 758; t. IV, s. 90, fol. 185; t. V, s. 7, fol. 6, s. 135, fol. 254.

32 Tak przy zakazie wnoszenia na teren „okopu” broni palnej i łuków oraz przy przestępstwie intencjonalnego zranienia lub zabójstwa w okolicach Warszawy w czasie zjazdu. Przepis ten wieńczy zdanie: „A ieśliby do sądu nie stanął ma bydź bannitus", VL t. III, s. 358, fol. 754; t. IV, s. 88, fol. 181-182; t. V, s. 6 , fol. 2; s. 133, fol. 250. Całość regulacji por. przyp. 52 .

33 „Które to wszystkie sprawy, o pomienione excessy y krzywdy, przed sąd Ichmci PP. Marszałków y Ichmci PP. Deputatów przypadaiące, pluralitas suff ragiorum ma concludere, duorum vel trium absentia non obstante", VL t. III, s. 360, fol. 758; t. IV, s. 90, fol. 185; t. V, s. 7, fol. 6; s. 135, fol. 255. 
z postępowania sędziego, czyli deputata (a także sługi marszałkowskiego), $z$ określonej sprawy, jeśli dotyczyła go ona w jakikolwiek sposób $^{34}$. Sądy Kapturowe na elekcjach miały oczywiście swojego protokolanta - pełnił tę funkcję pisarz ziemski warszawski, zobligowany do złożenia na tę okoliczność osobnej przysięgi i uzyskujący $z$ tego tytułu odrębne wynagrodzenie ${ }^{35}$. Wyroki podpisywało, poza pisarzem, trzech sędziów reprezentujących Małopolskę, Wielkopolskę i Litwę ${ }^{36}$. Co do pozostałych segmentów i elementów postępowania zastosowano interesujący zabieg, posłużono się mianowicie normą odsyłającą w kwestiach nieuregulowanych do przepisów o procedowaniu, a także bezpieczeństwie Trybunału Koronnego ${ }^{37}$

34 „A gdyby lub którego $z$ samych Ichmci, lub $z$ sług Ichmci sprawa przypadała, wychodzić od sądów powinni będą, y takowych spraw sądzić nie maią", VL t. III, s. 360, fol. 758; t. IV, s. 90, fol. 185; t. V, s. 7, fol. 6; s. 135 , fol. 254 .

35 Zgodnie $z$ przepisem miało być ono równe wynagrodzeniu pisarza ziemskiego sieradzkiego, niestety nawet niezwykle skrupulatny Lengnich nie wspomina, jak owa płaca się kształtowała i dlaczego to właśnie do salarium pisarza sieradzkiego, należało równać wynagrodzenie pisarza Kaptura, por. G. Lengnich, op.cit., s. 52. Nie było ono jednakowoż zapewne nazbyt wygórowane, skoro sam tekst przepisu stanowi, że pisarz „salarium ziemskim sieradzkim kontentować się będzie powinien”, por. VL t. III, s. 360, fol. 757; t. IV, s. 90, fol. 185; t. V, s. 7, fol. 6; s. 135, fol. 254.

36 „Dekreta sądu tego, podpisowane będą ręką trzech Ichmciów PP. Deputatów: iednego z Małey, drugiego z Wielkiey Polski, a trzeciego z W.X. L", VL t. III, s. 360, fol. 758; t. IV, s. 90, fol. 185; t. V, s. 7, fol. 6, s. 135 , fol. 254 .

37 To stosowanie przepisów dotyczących Trybunału do Kaptura Generalnego podkreślają przepisy porządkowe w dwu miejscach. Według przepisu Konfederacji Generalnej deputaci „wszystkie civiles et criminales actiones, któreby się sub Electionis actum, w onym głównym wszystkich Stanów zgromadzeniu trafiły, tali potestate et securitate iaką Trybunalskie Sądy maią [...] sądzić będą", VL t. III, s. 348, fol. 729; t. IV, s. 78, fol. 156; s. 487, fol. 1035; t. V s. 114-115, fol. 208. Natomiast zgodnie z Porzadkiem elekcyjnym: „Przy sądach Ichmciów PP. Marszałków oboyga narodów, z Ichmciami Pany deputaty, aby się każdy skromnie zachowywał pod winami w prawie, o bezpieczeństwie Sądów Trybunalskich opisanemi”, VL t. III, s. 360, fol. 757; t. IV, s. 89, fol. 184; t. V, s. 7, fol. 5; s. 134, fol. 254. 
(a zatem do ustawy erygującej Trybunał z roku 1578 oraz późniejszych jej „reasumpcji” i „korektur”38).

Powyżej zarysowane regulacje odnoszące się do kompetencji i procedur związanych $\mathrm{z}$ funkcjonowaniem zarówno sług marszałkowskich, jak i Kaptura Generalnego nie mogą dać nam pogłębionej wiedzy dotyczącej praktyki działania tych specyficznych organów. Sprawa ta wymaga dalszych badań niestety znane źródła nieformalne, które mogłyby rzucić więcej światła nie tyle na kwestię skuteczności Kaptura, co raczej na aspekty socjologiczne czy też kryminologiczne zjazdów elekcyjnych, a także na polityczne napięcia wewnątrz stanu szlacheckiego (których dowodem są przecież pełne kontrowersji i niezwykle ostrych polemik diariusze sesji kół rycerskich zjazdów elekcyjnych), nie dostarczają zbyt wielu cennych informacji. Nawet pełniący funkcje deputata autor znakomitej relacji z obrad sejmu elekcyjnego Michała Korybuta Wiśniowieckiego, Jan Antoni Chrapowicki, ogranicza się w swoim diariuszu do lapidarnych wzmianek o samym fakcie odbycia sądów, w zasadzie bez żadnych szczegółów odnoszących się do stanów faktycznych, treści rozstrzygnięć czy ciekawych epizodów $z$ rozpraw ${ }^{39}$. Możemy w tym miejscu jedynie stwierdzić, że Kaptur musiał rozstrzygać imponująco (może raczej zatrważająco) dużo spraw w rejestrach elekcji 1632 r. pozostały aż 4794 nierozstrzygnięte oskarżenia o naruszenie elekcyjnych norm porządkowych ${ }^{40}$. Swiadczy to niewątpliwie

38 Rzetelny i dogłębny przegląd ustawodawstwa dotyczącego Trybunału Koronnego zawiera klasyczne dzieło M. Goyskiego, Reformy Trybunału Koronnego, Lwów 1909, passim. Wiele ciekawych informacji odnoszących się do szeroko pojętego funkcjonowania Trybunału można odnaleźć w stosunkowo świeżym wydawnictwie autorstwa W. Bednaruka. Interesujące nas kwestie przebiegu postępowania sądowego, a zwłaszcza gwarancji bezpieczeństwa Trybunału zajmują tylko niewielką część rozważań, por. W. Bednaruk, Trybunał Koronny. Szlachecki sąd najwyższy w latach 1578-1794 , Lublin 2008, s. 131-191.

39 Por., pod datami 23-25, 27-29, 31 maja oraz 1, 3-8, 12-15, 19, 21-22 czerwca, J.A. Chrapowicki, op.cit., s. 492-499, 501-503, 55-508, 511-512. Autor relacji podkreśla jedynie, że sądzono wiele spraw skarbowych, co wskazuje, iż także one należały do zakresu kognicji Kaptura.

40 Por. W. Kaczorowski, op.cit., s. 232. 
o niewielkiej wydolności systemu zarówno w aspekcie prewencyjnym, jak i represyjnym.

Zgodnie $\mathrm{z}$ bardzo wątpliwą pod względem terminologii prawniczej relacją Chrapowickiego, Kaptur kończył się „limitą” i jednocześnie jego działalność „ustawała”, wraz z przysięgą nowoobranego króla ${ }^{41}$.

\section{Przepisy materialne}

Materialne przepisy porządkowe potraktowane zostaną przez nas nieco wybiórczo, albowiem niewielkie rozmiary niniejszego szkicu uniemożliwiają ich pełne i kompleksowe zanalizowanie. Zogniskujemy w związku z tym nasze rozważania na tych spośród nich, które są pomijane w literaturze przedmiotu, albo, choć są obecne w historiografii, to ich ujmowanie jest naszym zdaniem niepełne, nietrafne lub wymagające pewnych uwag natury typowo historycznoprawnej. Rozważania prowadzić będziemy według porządku wyznaczanego przedstawioną powyżej klasyfikacją przedmiotową.

$\mathrm{Na}$ pierwszą kategorię materialnych elekcyjnych przepisów porządkowych składały się normy dotyczące legalnego i bezpiecznego przeprowadzenia obrad i aktu elekcyjnego. By dokonać ich analizy, należy udzielić paru wskazówek odnoszących się do wyglądu i organizacji pola elekcyjnego. Możemy w nim wyodrębnić dwie sfery: pierwszą był tzw. okop elekcyjny - miejsce prowadzenia obrad senatu i koła poselskiego, drugą stanowił pozostały obszar, przeznaczony dla ogółu szlachty przybyłej na elekcję, której przysługiwało prawo do przysłuchiwania się obradom oraz do głosowania w ramach swoich województw na własnego kandydata. Obie sfery były oddzielone od pozostałej połaci pola elekcyjnego ziemnymi fortyfikacjami (stąd nazwa okop elekcyjny), których celem było powstrzymanie tłumów szlacheckich, obecnych na elekcji konno i w rynsztunku wojennym (na wzór pospolitego ruszenia czy tzw. okazowania), przed wtargnięciem na miejsce prowadzenia obrad,

41 „22 (czerwca) s(obota) - Limita sądów kapturowych, po których prezentowaliśmy się Królowi, donosząc, że one już ustały”, por. J.A. Chrapowicki, op.cit., s. 512. 
co mogło zagrozić nie tylko życiu i zdrowiu senatorów oraz posłów, ale także powadze i majestatowi samego zgromadzenia. „Okop” dzielił się z kolei na dwie części: „senatorską”, w której wznoszono specjalny budynek zwany „szopą” (gdzie odbywały się obrady senatu) ${ }^{42}$ oraz „rycerską” (tam oczywiście obradowali posłowie). Co istotne, część poselska była najważniejszym miejscem zjazdu elekcyjnego. To właśnie tam, a nie w szopie senatorskiej, odbywały się posłuchania posłów cudzoziemskich i tam właśnie, wbrew praktyce zwykłych sejmów, odbywały się wspólne kolokwia posłów i senatorów ${ }^{43}$.

Analizując przepisy odnoszące się do kwestii legalnego i bezpiecznego przeprowadzenia obrad sejmu elekcyjnego, zajmiemy się bliżej tylko trzema grupami regulacji. Pierwsza to zespół norm odnoszących się do zasad wyboru monarchy, $z$ jednej strony do reguł procedury wyborczej, a $z$ drugiej do zapewnienia nieskrępowanego wolnego głosu (libera vox). Przede wszystkim przepisem konfederacji generalnej zakazywano dokonywania rozłamu wśród zebranej na sejmie elekcyjnym szlachty (dokonywania tzw. dyssembracyi, mówiąc ściślej, oddzielania się pewnych grup secesjonistów, próbujących wykreować alternatywne względem ustalonego na kon-

42 Niewielkie środki znajdujące się w trawionym permanentnym deficytem skarbie, przy znaczącym pośpiechu w organizacji sejmu elekcyjnego, wynikającym $z$ niemożności przewidzenia śmierci królewskiej, powodowały, że jakość szopy senatorskiej była nie najlepsza, jeśli nie nieco uwłaczająca senatorom Rzeczypospolitej. Ciekawie obrazuje to anegdota zapisana przez Albrychta Radziwiłła, według której jeden ze sług przybyłego z opóźnieniem na zjazd elekcyjny wojewody bracławskiego Stanisława Rewery Potockiego, otrzymawszy zadanie przygotowania ad hoc w polu obiadu dla swego pryncypała, ulokował kuchnię w budynku, który zakwalifikował jako gospodarski, a którym było właśnie... miejsce obrad senatu, por. A.S. Radziwiłł, op.cit., s. 173 .

43 Najlepsze opisy pola elekcyjnego pozostawili: J.A. Chrościcki, Pola elekcyjne $i$ ich znaczenie dla rozwoju Warszawy, [w:] Spotkania $w$ willi Struvego. Wykłady o dziedzictwie kultury, red. K.J. Kwiecińska, Warszawa 2001, s. 185-199; M. Wagner, Pole elekcyjne królów polskich na woli (XVI-XVIII w.), [w:] Elekcje królów Polski w Warszawie na Woli. Upamiętnienie pola elekcyjnego w 400-lecie stołeczności Warszawy, red. M. Tarczyński, Warszawa 1997, s. 67-76; W. Kaczorowski, op.cit., s. 203-208. 
wokacji pole elekcyjne i dokonać wyboru „własnego” kandydata. Ujęcie sfery psychologicznej sprawcy obejmowało liczny katalog pobudek i celów przyświecających przestępcy: separatyzmy prowincjonalne, korupcję jak również racje polityczne (ponieważ podziały na fakcje, wg nawet światopoglądowego kryterium, uważano za szkodliwe dla demokracji, w przeciwieństwie do ujęcia nam współczesnego, które hołduje zasadom pluralizmu myśli i światopoglądów ${ }^{44}$. Nie zagłębiając się szczególnie w treść omawianej regulacji,

44, „[...] statecznym y iednostaynym zezwoleniem y świętym przyrzeczeniem, wszyscy [sobie - TK] spolnie obiecuiemy, y obowięzuiemy się wiarą, cnotą, poczciwością, y sumnieniem naszym, żadnego rozerwania między sobą ani dysmembracyi żadney nie czynić, ani dopuścić, iako w iedney a nierozdzielney Rzpltey ani iedna część przez drugiey Pana sobie obierać, y factione privata narabiać, abo kogo przez praktykę ku ubliżeniu wolney Elekcyi wsadzać na królestwo, biorąc albo pieniądze ku swemu pożytkowi, iako też ku zbieraniu ludzi, albo też obietnice, na iakie racye, albo na authorizacye $u$ Pana przyszłego. A ktoby za pewnym odniesieniem y słusznym dowodem, y przez scrutinium, takim się bydź pokazał, przed sądem, który sobie do tego y do inszych spraw na Elekcyi postanowiemy: tedy każdy taki ma bydź pro hoste patriae rozumian, y skaran, y od Elekcyi odstrychnion", VL t. II, s. 225, fol. 1055; t. III, s. 345, fol. 724; t. IV, s. 74, fol. 149; s. 483, fol. 1026; t. V, s. 111, fol. 200. Szczególnie interesujące jest tu szerokie zakrojenie ewentualnych czynów o znamionach korupcyjnych: obejmuje branie pieniędzy za popieranie określonego kandydata (,ku własnemu pożytkowi”). Pośrednictwo w tego typu praktykach (,ku zbieraniu ludzi"), a także udzielanie poparcia kandydatowi w zamian za obietnice przyszłych korzyści, tak pieniędzy, jak uzyskania korzystnego nadania ziemi lub urzędu albo też innej oczekiwanej decyzji administracyjnej (obietnice przyszłego króla „na jakieś racje, albo autoryzacje”). Uwaga A. Skrzypietz o tym, że łapówka wręczona i przyjęta realnie miała inny wymiar niż jej obietnica, jest zatem zasadna wyłącznie w sensie politycznym, sfinalizowanie transakcji bowiem w sposób oczywisty silniej wiązało beneficjenta łapówki z określonym kandydatem do korony, stanowiąc lepszą gwarancję autentycznego poparcia na polu elekcyjnym w trakcie głosowania, por. A. Skrzypietz, op.cit., s. 86. Warto podkreślić, że mimo powszechności przyjmowania korzyści majątkowych w zamian za popieranie określonego kandydata oskarżenia o przyjmowanie łapówek były przyjmowane z olbrzymim oburzeniem przez opinię publiczną, a osoby pomawiane broniły swego „dobrego imienia”, niezależnie od tego, czy ich sumienie naprawdę było czyste. Warto w tym miejscu przytoczyć interesującą relację dotyczącą publicznych oskarżeń (rzucanych jednego z posłów) o korupcję na najwyż- 
pragniemy jedynie zwrócić uwagę na niezwykle ciekawą sankcję, określaną jako „odstrychnienie od elekcji”, będącą swoistym pozbawieniem sprawcy przestępstwa pewnej grupy praw publicznych, w tym przypadku uczestnictwa w elekcji króla. Naturalnie podstawowe znaczenie miało zagrożenie karą banicji i pozbawienia majątku (tak należy rozumieć frazę sądzenia takiej osoby jako wroga ojczyzny, a zatem wg reguł postępowania ws. criminis laesae maiestatis), warto jednakże podkreślić interesujące postrzeganie przez „brać szlachecką” istoty i charakteru przewinienia przeciwko aktowi wyborczemu i wskazanie jako sankcji pozbawienia czynnego prawa wyborczego, jak również ogólnie możliwości partycypacji w jakiejkolwiek roli, w najdonioślejszym akcie zwierzchności szlachty Rzeczypospolitej w jej państwie. Warto podkreślić, że do secesji doszło już na pierwszej, postrzeganej jako wyjątkowo zgodna, elekcji Henryka Walezego (secesja grochowska) ${ }^{45}$, a na elekcji 1587 r. mieliśmy przez cały czas trwania obrad dwa alternatywne okopy elekcyjne, a także koła rycerskie, marszałków poselskich, egzorbitancje i pakta konwenta ${ }^{46}$. Na tejże elekcji dokonano także

szych szczeblach władzy, którą pozostawił w swym pamiętniku J.A. Chrapowicki pod datą 13 maja 1669 r.: „pan [Franciszek] Gałecki podpiwszy [mówił], że wie kto brał pieniądze na fakcyje francuskie i mianował panów łowczego koronnego [Jana Żelęckiego], kanclerza litewskiego [Krzysztofa Paca], wojewodę inowrocławskiego [Krzysztofa Żegockiego] [...]. Cały dzień na tym strawili”. Ciąg dalszy autor zapisał pod datą 14 maja: „Prosili [posłowie - TK] sądu z pana Gałeckiego, który mówił, że wie, iż pan łowczy [koronny] miał pieniądze królowej nieboszczki [Ludwiki Marii] i szafował nimi [...], że król przeszły posyłał do pana kanclerza [litewskiego] żeby ad bellum civile praktykował [...]. Wpadli na tę materią i było hałasu dosyć. Ja dałem medium, że albo tym się [będą] kontentowali, iż odwoła się pan Gałęcki [do sądu kapturowego - TK], albo to odłożyli. [...] pan marszałek [Szczęsny Kazimierz Potocki] zganił panu Gałeckiemu powiedziawszy, iż obiciens defecit in probationibus i miał privatim przeprosić pana kanclerza", J.A. Chrapowicki, op.cit., s. 486-487.

45 Por. S. Płaza, op.cit., s. 19-20.

46 Doskonałe diariusze wydane przez A. Sokołowskiego ukazują nam oddzielne relacje z obrad kół pro- i antykonwokacyjnego, por. Dyaryusze, wyd. A. Sokołowski, s. 57-158, 159-217; zob. także relację R. Heidensteina, op.cit., s. 222 i n. oraz opracowanie A. Pieńkowskiej, op.cit., passim. 
ostatecznie wyborów sprzecznych $\mathrm{z}$ pomienionym przepisem, wybrano bowiem Zygmunta bez udziału części senatorów i szlachty, a przede wszystkim bez zgody Litwinów, którzy według relacji pamiętnikarskiej poczuli się tym faktem obrażeni i nie chcieli uznać elekcji, mimo iż po upadku kandydatury rosyjskiej sprzyjali królewiczowi szwedzkiemu ${ }^{47}$. W konsekwencji mniejszościowe podówczas stronnictwo Zborowskich i Górki dokonało własnego wyboru, a konflikt o koronę rozstrzygnięto zbrojnie.

Podobnym przewinieniem przeciw istocie elekcji, choć o nieco innej specyfice, było nominowanie monarchy przez któregokolwiek senatora - zwłaszcza przez najwyższych godnością, z prymasem i marszałkiem wielkim na czele, $w$ ogóle $z$ pominięciem procedury wyborczej ${ }^{48}$. Taka sytuacja nastąpiła przed omawianym przez nas okresem historycznym, w roku 1575, kiedy arcybiskup gnieźnieński Jakub Uchański nominował na tron polski Maksymiliana II Cesarza Rzymskiego Narodu Niemieckiego ${ }^{49}$. Reminiscencje tego wydarzenia były w szlacheckim społeczeństwie nad wyraz silne, wynikało stąd wiele agresywnych zachowań rozjuszonego tłumu zebranej na elekcji szlachty, oskarżającej senatorów o „praktyki” i „knowania” z poszczególnymi kandydatami, w celu osadzenia ich na tronie $\mathrm{z}$ pominięciem woli szlachty wyrażonej w legalnym głosowaniu $^{50}$.

47 Por. R. Heidenstein, op.cit., s. 243.

48 „A ktoby bądź z Rad tak duchownych, iako y świeckich, albo Urzędników Koronnych, y W.K. Lit. y ex privatis personis ważył się nominować, publikować, albo koronować sine unanimi omnium Ordinum consensu, pana; tedy każdego takiego pro hoste patriae, mieć chcemy”, VL t. II, s. 225, fol. 1055; t. III, s. 345, fol. 724; t. IV, s. 74, fol. 149; s. 483, fol. 1026; t. V, s. 111 , fol. 200 .

49 Por. S. Płaza, op.cit., s. 72-73.

50 Najbardziej znany i wymowny incydent tego typu zostawił w swojej relacji z elekcji 1669 r. Jan Chryzostom Pasek: „Ozwie się jeden szlachcic z województwa łęczyckiego, którzy zaraz nad kołem stali na koniach: nie odzywajcie się kondeuszowie [chodzi o senatorskich zwolenników kandydatury księcia de Conde - TK], bo tu będą kule koło łba latały. Senator jeden odpowiedział mu coś crude. Kiedy to poczną ognia dawać: senatorowie $z$ miejsc w nogi między karety, pod krzesła; rozruch, tumult [...] obstąpiono circumcirca koło [...] zaczęto egzorty prawić: Zdrajcy! Wytniemy was, 
Drugą grupą regulacji wartą wspomnienia, która odnosiła się do bezpieczeństwa obrad publicznych, były przepisy reglamentujące posiadanie i używanie broni na polu elekcyjnym, zwłaszcza w „okopie”. W sposób wyraźny pozwalano na noszenie, nawet w czasie obrad, broni białej (jak ją określano: „zwyczajnej”), stanowiącej jeden $z$ istotniejszych atrybutów szlachectwa i będącej sui generis świadectwem jej rycerskiego charakteru, jako uprzywilejowanego stanu społecznego. Elekcyjne przepisy porządkowe ustalały egzemplifikacyjny katalog tejże broni, którą można było wnosić na miejsce obrad, wymieniały one miecz, szablę, korda, pałasz, koncerz i szpadę. W roku 1632, pod wpływem nieudanego, ale bulwersującego opinię publiczną zamachu szlachcica Piekarskiego na króla Zygmunta III, spod katalogu broni zwyczajnej wyłączono wyraźnie narzędzie, którym zamachowiec się posłużył, tzn. czekan, a także pokrewny puginał. Naturalnie wnoszenie na pole elekcyjne jakiejkolwiek innej broni, zwłaszcza palnej (zarówno długiej, jak i krótkiej) oraz relatywnie jeszcze popularnych łuków, zostało kategorycznie zabronione ${ }^{51}$. Inną, pokrewną względem wspomnianych

nie wypuścimy was stąd; darmo mięszcie Rzpltą". Po tym wydarzeniu, kiedy szlachta odeszła: „panowie biskupowie, senatorowie powyłazili spod krzeseł, spod karet, w pół ledwie żywi, i pojechali do gospód”. W następnych sesjach senatorowie bali się już uczestniczyć, „nie będąc securus zdrowia”. Szlachta w odpowiedzi zagroziła, „że już wojska zmykają się ku szopie”. Niejako w uzasadnieniu takich kroków szlachta apelowała do senatorów: „kto cnotliwy i senator, i kto chce, niech $z$ nami wyjedzie, obierzemy sobie pana. Kto nie wyjedzie będziemy go mieć za zdrajcę ojczyzny”, J.Ch. Pasek, Pamiętniki, Warszawa 1989, s. 197. Widać wyraźnie, że szlachta (oczywiście $\mathrm{w}$ formie całkowicie kompromitującej, sprzecznej z innymi przepisami porządkowymi, dotyczącymi wnoszenia na pole broni palnej czy wszczynania tumultów) pragnęła zmusić senatorów do uczestnictwa w elekcji na jej warunkach, tzn. zgodnie z prawem, obawiając się, iż „kondeuszowie”, spróbują dokonać nominacji wbrew woli narodu.

${ }^{51}$ Całość regulacji brzmiała następująco: ,aby żaden na ten plac, gdzie się Ichmość PP. Senatorowie $z$ Rycerstwem do Rady zieżdżają, z strzelbą, łukiem, ani inszą bronią oprócz zwyczayney; to iest, miecza, szable, korda, pałasza koncerza, szpady, przyieżdżać nie ważył się: a ktoby temu postanowieniu przecznym y przeciwnym był, ma bydź karan winą grzywien dwuchset y siedzeniem w wieży przez sześć niedziel. A ieśliby do sądu nie stanął ma bydź bannitus [...] oraz Czekanów, pu(g)inałów, aby żaden iadąc 
powyżej, normą, bardzo interesującą od strony prawnej, którą chcielibyśmy się zająć nieco bardziej szczegółowo, była regulacja zabraniająca dobywania broni białej w miejscu obrad. Co w kontekście tej regulacji interesujące, a niedostrzeżone w literaturze przedmiotu, to dychotomia charakteru normy o dobyciu broni w „okopie”. Dyspozycja przepisu porządkowego $z$ jednej strony zakazywała „tumultowania” uczestników zjazdu za pomocą „choćby dobycia broni” ${ }^{52}, \mathrm{z}$ drugiej wszakże strony $\mathrm{w}$ innym miejscu zakazywała wyciągania jej z pochwy, choćby bez zranienia czy sprowokowania kogokolwiek ${ }^{53}$. Znane nam źródła nie dają jasnego dowodu, ale możemy zaryzykować hipotezę, że pierwszy przepis regulował przestępstwo, przy którym dobrem chronionym było bezpieczeństwo uczestników zjazdu. Natomiast przedmiotem ochrony drugiego przepisu, normującego ewidentne przestępstwo formalne (tzn. bezskutkowe), był majestat zgromadzenia elekcyjnego, uosabiającego w sposób szczególny, wskutek nieobecności czynnika monarszego, majestat Rzeczypospolitej. Już sam fakt zaistnienia omawianej dychotomii zdaje się wskazywać na istnienie dwu różnych przedmiotów ochrony. Jako potwierdzenie tej hipotezy można uznać także ukształtowanie sankcji w obu omawianych regulacjach. Otóż $\mathrm{w}$ pierwszym przepisie (jak w większości elekcyjnych norm porządkowych) zastosowano jednolitą karę śmierci, bez względu na stan społeczny. W drugim natomiast zastosowano dyferencjację kar ze względu na przynależność stanową - plebejusz miał być karany śmiercią, szlachcicowi natomiast groziło zamknięcie w wieży i zapłata 200 grzywien. Fakt, że sprawę tę traktowano w sposób

do tego mieysca Elekcyi, y w nim samym y z niego odieżdżając, nie nosił, sub poena ducentarum marcarum", VL t. III, s. 358, fol. 754; t. IV, s. 88, fol. 181-182; t. V, s. 6 , fol. 2 ; s. 133 , fol. 250.

52 „[...] rozruch, abo zwadę, na mieyscu konsultacyom naznaczonym, przez dobycie tylko broni, abo uderzenie jakiekolwiek, ktoby zaczął ma bydź na gardle karany praevia inquisitione", VL t. III, s. 359, fol. 755; t. IV, s. 88 , fol. 182 ; t. V, s. 6 , fol. 3 ; s. 133 , fol. 251.

53 „Broni ktoby dobył w okopie do konsultacyi naznaczonym, choćby nie ranił, ieżeli szlachcic, ma bydź karan siedzeniem w wieży przez sześć niedziel, y dwiema sty grzwien: ieżeli plebeius, gardłem karan bydź ma”, VL t. III, s. 359, fol. 755; t. IV, s. 88, fol. 182; t. V, s. 6, fol. 3; s. 133, fol. 251 . 
wyjątkowy, ukazuje także wzmianka zmieszczona w Prawie pospolitym Królestwa Polskiego G. Lengnicha, który wymieniając przypadki naruszenia porządku sejmu elekcyjnego poprzedzającego wybór Augusta II, wskazuje na trzy w jego opinii najbardziej bulwersujące: groźby zebranej szlachty wobec senatorów i straży marszałkowskiej, zastrzelenie w kole szlachcica (stojącego w bezpośrednim pobliżu marszałka poselskiego) oraz właśnie dobycie szabli w miejscu obrad ${ }^{54}$. Nie odnajdujemy niestety $w$ diariuszach zapisów tego typu incydentów, stąd trudno o klarowne i kategoryczne sądy, ale tezę naszą może potwierdzać wydarzenie $z$ sejmu elekcyjnego 1632 r., kiedy poseł Adam Kisiel, w celu podkreślenia swego zdania w trakcie ostrej polemiki z wojewodą wileńskim Lwem Sapiehą, schwycił za rękojeść szabli, grożąc przy okazji wojewodzie, że na innym miejscu to broń rozstrzygnęłaby kontrowersję między nimi, za co został surowo zganiony przez marszałka i ogół posłów, nie wiadomo tylko, na ile była to krytyka słów i intencji Kisiela, a na ile zaważył fakt schwycenia za broń w miejscu obrad sejmu elekcyjnego ${ }^{55}$. Sprawa ta wymaga naturalnie dalszej szczegółowej analizy na bazie źródeł nieformalnych.

Trzecią grupę stanowił zestaw norm ustanawiający wejścia prowadzące do okopu elekcyjnego. Wiodły tam zasadniczo trzy bramy: południowa - przeznaczona dla posłów z Małopolski, zachodnia dla posłów litewskich i wschodnia - dla tych z Wielkopolski ${ }^{56}$. Wyznaczał je marszałek poselski na początku sejmu elekcyjnego

54 G. Lengnich, op.cit., s. 53.

55 Incydent opisuje nieoceniony A.S. Radziwiłł, op.cit., s. 161.

56 Włodzimierz Kaczorowski, a także Marek Wagner, kierując się zapewne usytuowaniem geograficznym, nietrafnie podają, że to wschodnia brama przeznaczona była dla posłów z Wielkiego Księstwa, a zachodnia dla tych z Wielkopolski, por. W. Kaczorowski, op.cit., s. 204-205; M. Wagner, op.cit., s. 70. Nie udało nam się wyjaśnić tej dość aberracyjnej regulacji, wiadomo tylko, że do zmiany omawianej normy doszło dopiero w czasie elekcji Stanisława Augusta Poniatowskiego, kiedy na skutek niedyspozycji marszałka wielkiego koronnego Stanisława Lubomirskiego to marszałek wielki litewski Ignacy Ogiński, dla wygody rodaków, zdecydował o odmiennym przydzielaniu bram, por. H. Rutkowski, Wolna elekcja-zasady i praktyka wybierania królów polskich, [w:] Elekcje królów, red. M. Tarczyński, s. $48-49$. 
(gdy infrastruktura elekcyjna była gotowa, ewentualnie odnowiona) i nakazywał je oznaczyć za pomocą specjalnych słupów „Z odpowiednimi napisami”, wbijanych w ziemię ${ }^{57}$. Oczywistym celem omawianych działań było ustalenie jasnych reguł umożliwiających skuteczniejsze zapanowanie nad tłumem, zwłaszcza w sytuacji niebezpieczeństwa, np. tumultów, kiedy bramy pełniły w zasadzie rolę wyjść ewakuacyjnych. Stąd właśnie jeden z przepisów karnych penalizował czynienie zwad w trakcie przejeżdżania przez bramę, co mogło grozić dezorganizacją i paniką, a w konsekwencji prowadzić do znanych nam także współcześnie przykładów tratowania ludzi przez rozjuszony tłum ${ }^{58}$. Podobny cel przyświecał bezwzględnemu zakazowi wjeżdżania na pole elekcyjne $z$ wozami i końmi, mogącymi zablokować przejścia ${ }^{59}$. Warto podkreślić, że bramy pełniły także inną istotną funkcję symboliczną, albowiem po dokonaniu aktu wyboru i ogłoszeniu jego wyników przez prymasa drugiego obwieszczenia rezultatów elekcji dokonywał marszałek wielki koronny w każdej $z$ tych trzech bram ${ }^{60}$.

Niezwykle istotną kwestią związaną z organizacją zjazdu elekcyjnego, wyznaczającą zakres kolejnej kategorii przedmiotowej elekcyjnych przepisów porządkowych, było wyznaczenie gospod dla

\footnotetext{
57 Por. A.S. Radziwiłł, op.cit., s. 146.

58 „Ktoby w przeieżdżaniu do tych bram, abo w odieżdżaniu, zwadę iaką uczynił, ma bydź także arbitraria poena civili karany”, VL t. III, 359, fol. 755; t. IV, s. 89, fol. 183 ; t. V, s. 6 , fol. 4; s. 134, fol. 252. Na trochę inny problem wskazują wydarzenia elekcji 1669 r., kiedy to senatorowie obawiali się o swoje zdrowie i życie, albowiem rozjuszona szlachta strzelała w ich kierunku z broni palnej ruszyli do bram, chcąc uciec z pola. Wyjścia zostały jednak zablokowane przez szlachtę, która zmusiła senatorów do powrotu na miejsce, por. G. Lengnich, op.cit., s. 53.

59 „Na ten plac gdzie stany zasiadają, aby żaden, tak końmi, iako wozami wieżdżać, a osobliwie w okop, nie ważył się: a ktoby za napomniem Urzędu Ichmociów Panów Marszałków, tak Koronnych iako W.X.L. Czynić tego nie przestał, ma bydź poena arbitraria civili sądu pomienionego karany”. Zwraca tu uwage ciekawa instytucja napomnienia, która miała poprzedzać wszczynanie sprawy w Kapturze Generalnym. Był zapewne to pragmatyczny zabieg mający odciążyć sąd elekcyjny.

60 Por. W. Skrzetuski, Prawo polityczne narodu polskiego, t. I, Warszawa 1782, s. 94.
} 
uczestników zjazdu. Jako że Warszawa w XVII w. nie była metropolią, nawet jak na polskie warunki, gospody musiały być rozsiane po niemal 250 okolicznych miejscowościach w promieniu ok. $30 \mathrm{~km}^{61}$. Przepisy porządkowe nakładały na marszałka wielkiego koronnego obowiązek reglamentowania i zarządzania przyznawaniem gospod ${ }^{62}$. Należy wszakże podkreślić, że obowiązek ten, wespół $z$ innymi licznymi zadaniami obciążającymi urząd marszałkowski w czasie bezkrólewia, przekraczał znacząco fizyczne i finansowe możliwości marszałka i jego straży, stąd zjazdy konwokacyjne przychodziły im $z$ pomocą, mianując deputatów szlacheckich mających przejąć część obowiązków związanych $z$ wyznaczaniem gospod ${ }^{63}$. Powoływano przy tym specjalny urząd „stanowniczego”, którego

61 Rozproszenie gospód spowodowało znaczące utrudnienia w dotarciu na obrady sejmowe. W sposób szczególny uskarżali się na to posłowie Wielkiego Księstwa Litewskiego mieszkający za Wisłą, którzy musieli się codziennie przeprawiać przez rzekę. Więcej informacji o problemach związanych $z$ techniczną stroną rozdysponowywania gospód odnajdzie Czytelnik w monograficznych opracowaniach sejmów elekcyjnych, por. M. Chmielewska, Sejm elekcyjny, s. 166; W. Kaczorowski, op.cit., s. 198-203.

62 Zgodnie z przepisem Konfederacji Generalnej 1632 r.: „Ich MM. PP. Marszałkom oboyga narodu moc zupełną daiemy, aby iako na Seymach zwykli gospody z Urzędu swego rozdawać; tak żeby woiewództwom, Ziemiom y Powiatom Koronnym, y W.X. Lit. y Ziem do nich należących, stanowiska (dwory iednak y domy szlacheckie ab isto onere wyiąwszy) po Woiewództwach rozdawali”, VL, t. III, s. 347, fol. 729 - przepis ten wyraźnie nakazywał marszałkom rozdysponowanie gospód, wyłączając wszakże te będące własnością szlachecką. W innym miejscu konfederacje wszystkich bezkrólewi stanowiły: „A iż nie wszystkim blisko Warszawy stać przyidzie, przetoż ieśliby kiedy $z$ odległych stanowisk Posłowie, abo Deputaci od Woiewództw, Ziem lub Powiatów do głównego koła wysłać chciano, tedy in eum finem w mieście Warszawskim, more solito, PP. Marszałkowie Poselskie gospody wszystkim Woiewództwom, Ziemiom y Powiatom, z których posłowie na Seymy wysyłani bywaią, rozdadzą”, VL, t. III, s. 347-348, fol. 729; t. IV, s. $77-78$, fol. 156; s. 487 , fol. 1034 ; t. V, s. 114 , fol. 208 - przepis ten jest dobitnym wyrazem obawy, by nie urazić posłów wysłanych z odleglejszych terenów Rzeczypospolitej, szczególnie z Wielkiego Księstwa Litewskiego.

63 O deputatach wyznaczanych przez marszałków poselskich (zarówno na konwokacji, jak ci samej elekcji) wspomina M. Chmielewska, Sejm elekcyjny, s. 166. 
obowiązkiem było oznaczanie gospód, najętych lub zarezerwowanych, próba zajęcia gospody przez zamazanie czy usunięcie oznaczenia była surowo karanym przestępstwem ${ }^{64}$.

Szczególnym problemem było wyznaczenie gospód dla oficjeli zagranicznych, polscy magnaci bowiem mieli, co do zasady, swoje własne nieruchomości w Warszawie, wielu spośród przedstawicieli szlachty, zwłaszcza zamożniejszej, także, a pozostali starali się nająć gospodę jak najszybciej po uzyskaniu informacji o terminie zjazdu. Deficyt dostępnych lokali mieszkalnych przy niewysokich zdolnościach (ale także, co przyznajmy, marnych materialnych możliwościach) organizatorów zjazdów elekcyjnych powodował, że przed samym sejmem nie istniał żaden legalny sposób zakwaterowania posła zza granicy, co groziło naturalnie nie lada skandalem międzynarodowym. Niewątpliwie trudno było organizującym elekcję przewidzieć: kiedy, ilu, jakiej rangi i z jakich krajów posłów należy się spodziewać na zjeździe, informację tę podawano w zasadzie w ostatniej chwili ${ }^{65}$. Szczególnym problemem był zwyczajowy zakaz kwaterowania posłów cudzoziemskich w samej Warszawie, ze

64 „A ktoby herb oddarł [z czyjejś gospody - TK], abo napis stanowniczego zmazał, ieżeli szlachcic, winą dwuchset grzywien y siedzeniem w wieży przez Elekcyą: a plebeius ucięciem ręki karany bydź ma, premissa inquisitione officiosa", VL t. III, s. 358, fol. 755; t. IV, s. 88, fol. 182; t. V, s. 6, fol. 3; t. V, s. 133, fol. 251. Istniały oczywiście mniej subtelne sposoby zdobywania zakwaterowania niż fałszowanie oznaczeń, niejednokrotnie zdarzały się zbrojne najazdy na położone niedaleko Warszawy nieruchomości, szczególnie na wygodne dworki szlacheckie i plebanie, co naturalnie było odrębnym przestępstwem, $z$ którym wiązała się nie tylko sankcja represyjna, ale i oczywisty obowiązek naprawienia wyrządzonej szkody majątkowej, do powstania której przy takich incydentach musiało dochodzić („A ktoby w dwory, tak duchowne iako y szlacheckie, gwałtownie bez pozwolenia panów wiachał: powinien $z$ nich ustąpić za pierwszą instancyą prawną y winę dwóch set grzywien parti et iudico totidem zapłacić, y szkody nagrodzić”), VL t. III, s. 358, fol. 755; t. IV, s. 88, fol. 182; t. V, s. 6, fol. 3; t. V, s. 133, fol. 251.

65 Oficjalna prośba posłów Gustawa Adolfa o naznaczenie gospody na elekcji 1632 r. nastąpiła 27 września, czyli w dniu rozpoczęcia sejmu, por. A.S. Radziwiłł, op.cit., s. 143. 
względu na zagrożenia korupcją i "praktykami”66. Stanowiło to kanwę licznych konfliktów rozstrzyganych przez komisje powoływane uchwałą koła rycerskiego, przy czym na sejmie elekcyjnym 1674 r. doszło nawet do tego, iż jeden z posłów wniósł pod obrady plenarne koła rycerskiego sejmu elekcyjnego osobistą skargę o to, że został usunięty $z$ legalnie zajmowanej przez siebie gospody, w której zakwaterowano posła „moskiewskiego”67. Co oczywiste, obowiązki kwaterunkowe były nałożone na mieszczan Warszawy i okolic, co musiało być dla nich wielką uciążliwością i naruszało ich prawo do dysponowania własnymi nieruchomościami ${ }^{68}$.

Odrębnym problemem, wytyczający jednocześnie zakres kolejnej grupy przedmiotowej elekcyjnych norm porządkowych, była kwestia mostu. Historia infrastruktury mającej ułatwić przeprawę przez Wisłę w faktycznej (od czasów Zygmunta III) rezydencji królów, czyli jak powiedzielibyśmy dzisiaj stolicy państwa, jest zagadnieniem tyle interesującym, co pouczającym w kwestii skuteczności funkcjonowania aparatu państwowego oraz ukształtowania i wydolności finansów publicznych w Rzeczypospolitej. W połowie XVI w., za panowania Zygmunta Augusta, zlecono budowę mostu, którego wykonanie było chwalone przez ówczesnych architektów, nie wytrzymał on jednak próby czasu (ze względu na brak działań konserwatorskich) i szybko się zawalił. Jawnym dowodem dyspersji i atrofii władzy państwowej Rzeczypospolitej jest fakt, że nie przedsięwzięto inicjatywy odbudowy mostu aż do czasów stanisławowskich, kiedy to powstał tzw. most Ponińskiego. Dlatego właśnie

66 „[...] legaci stanęli gospodą w osobnych wioskach przyległych do Woli, a to $z$ dawnego zwyczaju, zabranizającego pod takowy czas wyznaczać posłom zagranicznym stanowiska w stolicy lub w miejscu elekcyi, skądby łatwo tajemnic Rzeczypospolitej dociekać albo bieg elekcyi tamować i przerywać mogli”, P. Piasecki, op.cit., s. 376.

67 W diariuszu sejmu pod datą 24 kwietnia 1674 r. odnajdujemy adnotację następującą: „Uskarżał się w głosie swym J.MćPan Chorąży Łęczycki, że mu gospodę za pieniądze naiętą [...] wzięto, y tam Posła Moskiewskiego postawiono. Wynaleziono wtedy medium: w nagrodę tey gospody inną tak wygodną J. MćPan Marszałek Panu Chorążemu ex officio naznaczył", Diarius seymu, [w:] Dwa diariusze, wyd. F. Kluczycki, s. 46.

68 Szerzej, zob. A. Sokołowska, op.cit., s. 84-85. 
przed każdą elekcją prymas jako interrex specjalnym uniwersałem nakazywał podskarbiemu wygospodarowanie środków na wybudowanie tymczasowej przeprawy przez rzekę ${ }^{69}$. Koszt budowy takiego mostu nie był wcale wielki - Albrycht Radziwiłł podaje jego wycenę na $14000 \mathrm{zt}^{70}$. Chroniczny brak pieniędzy w skarbie Rzeczypospolitej i niewielki, jak na ówczesne realia, czas między śmiercią króla a sejmem konwokacyjnym, na którym ustalano miejsce elekcji (nie musiało ono przecież być wyznaczone na okolice Warszawy), oraz między konwokacją a elekcją powodował, że prowizoryczny most budowano naprędce, przy niewystarczającej liczbie środków finansowych oraz siły roboczej, a także materiału. Fakt, że był to most „łyżwowy” - tzn. nieopierający się na umocowanych w dnie palach, lecz wznoszony na miejskich szkutach rzecznych, powodował jego olbrzymią niestabilność oraz duże prawdopodobieństwo wpadnięcia osób do wody lub nawet zawalenia się całej konstrukcji ${ }^{71}$. Dodatkowym problemem był fakt, że most mimo swoich niedostatków pełnił gigantyczną rolę dla warszawskiego mieszczaństwa, pozbawionego na co dzień relatywnie wygodnej przeprawy przez rzekę, przez co ruch i obciążenie mostu było w czasie zjazdów elekcyjnych ogromne. W odpowiedzi na intensywność przepraw dokonano w przepisach porządkowych specyficznego uregulowania zasad ruchu, który był co do zasady dwustronny, ale w godzinach od 8:00 do 9:00 oraz od 16:00 do

69 W treści takiego uniwersału zawarty był apel do mieszczan dysponujących barkami i szkutami o udostępnienie ich na zasadzie odpłatności na rzecz budowy mosty (niezbyt ochocze oddawanie tychże środków, a nawet uciekanie $z$ nimi w dół rzeki wskazuje na pewien sceptycyzm, co do pewności zapłaty). Dokument nie zawierał szczegółów technicznych, nawet tego, czy odpowiedzialny za budowę jest urząd marszałkowski, czy władze miejskie. Nie wskazano także źródła czerpania drewna koniecznego na budowę. Tylko „papierowa” była decyzja o zabezpieczeniu w skarbie koronnym i litewskim potrzebnych środków finansowych. Barwnie i wnikliwie o sprawie mostu pisze W. Kaczorowski, op.cit., s. 197-198, 220-221; a także w odrębnym szkicu: idem, Problem mostu warszawskiego na sejmie konwokacyjnym i elekcyjnym 1632 roku, Kronika Warszawy 1983, nr 1, s. 93-103.

70 A.S. Radziwiłł, op.cit., s. 142.

71 W. Kaczorowski, Sejmy konwokacyjny i elekcyjny, s. 221. 
17:00 zmieniano jego organizację na jednostronną, tak by uczestnicy zjazdu elekcyjnego mogli: rano dotrzeć na pole elekcyjne, a po południu $z$ niego wrócić ${ }^{72}$. Oczywiście regulacja ta nie mogła sprawdzić się w praktyce, sesji nigdy nie zaczynano o godzinie 10:00, tak jak nigdy ich nie kończono przed godziną 16:00, co musiało dogłębnie dezorganizować przeprawę ${ }^{73}$. Jako że przepisy dotyczące mostu są relatywnie dobrze opisane $\mathrm{w}$ literaturze ${ }^{74}$, wspomnimy jeszcze tylko o jednym, mianowicie normie prawnokarnej penalizującej intencjonalne zrzucanie innych osób do rzeki. Jest to regulacja interesująca ze względu na zastosowanie specyficznego, znanego także współczesnemu prawu karnemu, obostrze-

72 „Aby żaden $z$ furmanów y przekupniów od ósmey $z$ rana do dziewiątey godziny na półzegarzu, do Warszawy przez most nie wieżdżał, ani w ulicach, y w mieście, y na przedmieściach nie zacieśniał: także po południu od czwatey aż do piątey godziny, przez most aby nie iechał; a to dla zatarcia y zacieśnienia IchMci tych, którzy z tamtey strony ku sprawom Rzpltey zieżdżać się, y nazad do stanowisk swoich wracać będą, ponieważ czas ten zieżdżania się, Ichmść wszyscy sobie naznaczyli, czego warta marszałkowska ma pilnować”, VL t. III, s. 359, fol. 756; t. IV, s. 89, fol. 183-184; t. V, s. 7 , fol. 4; t. V, s. 134 , fol. 253. W świetle wyraźnego brzmienia przepisu nie rozumiemy, na jakich źródłach niektórzy autorzy opierają konstatację, jakoby ruch jednostronny obowiązywał w godzinach 7:00-9:00 rano i 15:00-17:00 po południu, por. W. Kaczorowski, Sejmy konwokacyjny i elekcyjny, s. 220; idem, Problem mostu, s. 101; M. Wagner, op.cit., s. 82. Prawidłowo, zgodnie $z$ brzmieniem przepisu ujmuje tę kwestię M. Chmielewska, Sejm elekcyjny, s. 163; eadem, Życie codzienne, s. 121.

73 Szczególnie dużo informacji pozostawił na ten temat Albrycht Radziwiłł w opisie elekcji 1632 r., pod datami 14, 15, 19, 23 i 30 października oraz 2, 4 i 5 listopada, cytując marszałka sejmu Jakuba Sobieskiego, który napominał posłów, by przychodzili na sesję punktualnie. Problem polegał na tym, że posłowie schodzili się w zasadzie do godziny... 12:00, a każdy nowo przybyły stwierdzał, iż żąda powtórzenia wszystkiego, co do tej pory ustalono. Powodowało to niezwykłą dezorganizację i przeciągało obrady, a przy okazji czyniło kompletnie bezużytecznym przepis precyzujący zasady organizacji ruchu na moście, por. A.S. Radziwiłł, op.cit., s. 155-156, 157, 162, 168, 179,185, 193, 198.

74 Por. szczególnie: M. Chmielewska, Sejm elekcyjny, s. 163; eadem, Życie codzienne, s. 120-121; W. Kaczorowski, Sejm konwokacyjny i elekcyjny, s. 220, 231; idem, Problem mostu, s. 101; A. Sokołowska, Elekcje na Woli, [w:] Elekcje królów, red. M. Tarczyński, s. 81 i n. 
nia sankcji przez następstwo. Otóż za zepchnięcie $z$ mostu groziła kara siedzenia w wieży przez rok i sześć tygodni oraz zapłaty 200 grzywien, jeśli natomiast zepchnięty zginął na skutek zepchnięcia przez utonięcie, winny miał być ukarany śmiercią ${ }^{75}$.

W kwestii kolejnej kategorii przedmiotowej elekcyjnych przepisów porządkowych, ogniskującej się na problemie obrotu towarowego w trakcie zjazdu, pragniemy zanalizować jedynie dwa przepisy. Wyjątkowy jest zwłaszcza pierwszy, dotyczący sprawy o szczególnym znaczeniu i charakterze, regulował bowiem zagadnienie jednolitego środka płatniczego na terenie zjazdu. Zagadnienie polityki monetarnej Rzeczypospolitej było jednym z najbardziej ważkich problemów w ówczesnej polityce państwa - nie bez kozery sprawy związane $z$ biciem monety i nadużyciami w tej sferze marszałek sejmu elekcyjnego 1632 r. Jakub Sobieski nazwał „egzorbitancją nad egzorbitancjami"76. Właśnie obradom koła poselskiego poprzedzającym wybór na tron Władysława IV towarzyszył znaczący problem różnicy w wartości ortów tzw. królewieckich, których wartość nominalna wynosiła 16 groszy, o 1 grosz mniej niż powszechnie używanych ortów wybijanych w królewskich mennicach w Bydgoszczy i Gdańsku. Stanowiło to niemały problem przy obrocie towarowym i respektowaniu ustalanej przez marszałka taksy na określone towary. Co ciekawe, mieszczanie Warszawy byli gotowi przyjmować orty królewieckie, a używali ich głównie szlachcice $z$ Litwy, co determinowało bezpośrednie zaangażowanie obu tych grup na rzecz przeforsowania regulacji, by w trakcie elekcji ustalono jednolity kurs walutowy. Normatywna realizacja tego żądania napotykała wszakże na olbrzymi problem w postaci prawnej nielegalności ortów królewieckich, które zostały usunięte z obiegu na sejmie 1627 r., ponieważ uznano, że przez ich wybijanie elektor brandenburski uzurpuje sobie uprawnienia należne Rzeczypospolitej. Ostatecznie ustalono, iż orty powinny mieć równą wartość (domyślnie 17 gro-

75 „Ieśliby ieden drugiego umyślnie $z$ mostu zepchnął, ma bydź karan siedzeniem w wieży rok y sześć niedziel, y dwiema sty czterdziestą grzywien: a ieżeli zepchniony utonął, ma gardło tracić ten, który zepchnął", VL t. III, s. 359, fol. 755; t. IV, s. 88, fol. 183; t. V, s. 6, fol. 3; t. V, s. 133, fol. 251-252.

76 Por. A.S. Radziwiłł, op.cit., s. 173. 
szy), a używanie ich będzie dozwolone, ale tylko przez czas sejmu elekcyjnego, tylko na terenie zjazdu i tylko tych wybitych przed delegalizacją ${ }^{77}$. Sprawę tę dogłębnie zanalizował W. Kaczorowski zarówno $\mathrm{w}$ aspekcie prawnym, jak i politycznym ${ }^{78}$. Niestety nie wiemy, jaki wpływ miała ta regulacja na obrót (pieniądz gorszy wypiera przecież lepszy!), sprawa ta wymaga zatem dalszych badań źródłowych. Nie ulega wszakże najmniejszej wątpliwości, że zagadnienie to pokazuje, $z$ jak szerokim wachlarzem problemów musieli sobie radzić organizatorzy zjazdów elekcyjnych i jak trudnym przedsięwzięciem było przygotowanie go w warunkach państwa feudalnego, niejednolitego pod względem prawnym i ekonomicznym.

Drugim problemem dotyczącym reglamentacji swobodnego obrotu towarami była sprawa związana nierozerwalnie $z$ kulturą tak prawną, jak osobistą braci szlacheckiej. Chodziło mianowicie o handel napojami alkoholowymi na terenie zjazdu, szczególnie na polu elekcyjnym. Regulacja ta ze względu na swój charakter budziła oczywiście znaczące zainteresowanie wśród historyków ${ }^{79}$. Ze swej strony chcielibyśmy jedynie zwrócić uwagę na bardzo interesujące ukształtowanie zakresu podmiotowego (nie było to przestępstwo powszechne!) oraz sankcji. Przewinienia polegającego na przetransportowaniu napojów alkoholowych w pobliże pola elekcyjnego i próbie jego sprzedaży mógł dopuścić się jedynie mieszczański kupiec, co oznaczało w zasadzie wyłączenie penalizacji posiadania przez szlachtę alkoholu na własny użytek. Karą za omawiane przestępstwo miała być konfiskata ( $\mathrm{w}$ formie zbliżonej w zasadzie do spotykanego we współczesnym systemie prawnym środka karnego przepadku) ${ }^{80}$. Ciekawa, a wymagająca jeszcze dodatkowych badań

77 Co istotne nazwa ortów nie pada, przepis był sformułowany abstrakcyjnie: „Moneta Rzpltey y tych którzy in corpore, ac simul in fide et obsequio Reipubl: są, y jus cudendae monetae a Reipubl: concessum maią ta tylko, która ante cesationem generalem, secundum praescriptum legum bita, aby równą ceną szła, waruiemy", VL t. III, s. 359, fol. 756; t. IV, s. 89, fol. 184; t. V, s. 7, fol. 5; t. V, s. 134, fol. 253.

78 Por. W. Kaczorowski, Sejm konwokacyjny i elekcyjny, s. 228-230.

79 Por. ibidem, s. 231; A. Sokołowska, op.cit., s. 83.

80 „Aby się żaden nie ważył około tego placu, gdzie Rada z rycerstwem zasiadać będzie, wozić gorzałek, wina, piwa, y inszego trunku do szynko- 
źródłowych, wydaje się kwestia rozstrzygnięcia, czy alkohol przywieziony i już sprzedany któremuś $z$ uczestników zjazdu także podlegał konfiskacie. Niewątpliwie interesujące są także losy już skonfiskowanego towaru kupca, trudno bowiem uwierzyć, że alkohol po prostu wylewano.

Kolejną grupą norm są regulacje odnoszące się do bezpieczeństwa pożarowego. Miały one szczególne znaczenie nie tylko w odniesieniu do oczywistych kwestii zagrożenia życia, zdrowia i mienia ludzi, ale również w perspektywie podkreślanego już na kartach szkicu niniejszego deficytu lokali mieszkalnych, których nagły ubytek mógł pogłębić dezorganizację związaną z niemożnością zakwaterowania uczestników zjazdu. Zgodnie z relacją Jana Antoniego Chrapowickiego $\mathrm{w}$ jednym $\mathrm{z}$ dwu pożarów, które wybuchły w Warszawie w trakcie zjazdu z roku 1669, spaliło się mniej więcej 150 kamienic, co stanowiło ok. 10\% ówczesnej zabudowy mieszkalnej stolicy ${ }^{81}$. W ówczesnej Polsce nie istniały jeszcze wyspecjalizowane służby, których zadaniem byłoby gaszenie pożarów, stąd obowiązki w tym względzie rozkładano na gospodarzy, tzn. właścicieli i zarządców domów mieszkalnych, jak również osoby prowadzące publiczne kuchnie ${ }^{82}$. Penalizowane było przy tym intencjonalne zniszczenie lub uszkodzenie oprzyrządowania przeciwpo-

wania, pod utraceniem tego co przywiezie", VL t. III, s. 359, fol. 757; t. IV, s. 89, fol. 184 ; t. V, s. 7, fol. 4; t. V, s. 134, fol. 253.

81 Autor relacji podkreśla, że w trakcie pożaru „rabowano srodze”, co może sugerować intencjonalne podpalenie w celach rabunkowych, por. J.A. Chrapowicki, op.cit., s. 502-503. Pogłoski o podpaleniach były w czasie zjazdu elekcyjnego 1669 r. dość powszechne, zob. M. Chmielewska, Życie codzienne, s. 122.

Dane o zabudowie Warszawy w 1669 r. zaczerpnęliśmy z wielotomowego wydawnictwa Dzieje Warszawy, red. S. Kieniewicz, t. II: Warszawa w latach 1526-1795, Warszawa 1984, s. 190, 192.

82 „[...] każdy gospodarz powinien mieć wodę w statkach, osęki, drabiny, y insze rzeczy do tego należące: także też y przy kuchniach w rynku postawionych aby statki dla niebezpieczeństwa ogniowego zawsze gotowe były; czego Urząd Icmci PP. Marszałków przestrzegać ma y w tym nieposłusznych y niedbałych, winą czternastu grzywien karać”, VL t. III, s. 359, fol. 757; t. IV, s. 89, fol. 184; t. V, s. 7, fol. 5; t. V, s. 134, fol. 253. 
żarowego, dodawano tu oczywiste unormowanie obowiązku naprawienia szkody ${ }^{83}$.

W ostatniej grupie materialnych przepisów porządkowych, którą nazwaliśmy nieprecyzyjnie normami dotyczącymi zachowania porządku publicznego w czasie zjazdu, omówimy tylko dwie regulacje. Pierwsza dotyczyła partycypacji w zjeździe wojska kwarcianego oraz kozackiego. Obie te grupy, reprezentujące znaczący potencjał i wpływ polityczny (dysponowały przecież groźnymi dla państwa instrumentami, pierwsza - konfederacjami wojskowymi, druga - po prostu buntami), będące, mówiąc językiem współczesnym, istotnymi "grupami nacisku”, uzurpowały sobie prawo do czynnej partycypacji w sejmie elekcyjnym i w wyborze monarchy. W obu przypadkach oznaczałoby to oczywiście możliwość wywierania presji wojskowej i likwidację wolności elekcji. Szczególne oburzenie wzbudzały tu postulaty kozaków, których uznawano przecież w zasadzie za chłopów (zwłaszcza grupę nieformalną, czyli tzw. kozaków nierejestrowych) ${ }^{84}$. Powszechnie przyjętą zasadą, wyrażoną w jednym $z$ elekcyjnych przepisów porządkowych, było przyjmowanie poselstw od kwarcianych i zaporożców w celu wysłuchania ich postulatów (sejm elekcyjny był niejednokrotnie zmuszany do rozstrzygania spraw związanych $\mathrm{z}$ zapłatą wojsku należnego żołdu). Ustanowiono jednak dość restrykcyjne limity liczebności tych poselstw wojskowych, które były przestrzegane znacznie lepiej niż regulacje ograniczające liczebność pocztów magnackich ${ }^{85}$.

83 „A ktoby statki $z$ wodą, y insze potrzeby do tego należące, rąbał y psował, tak ma bedź karany siedzeniem w wieży przez sześć niedziel, y nagrodzeniem szkody”, VL t. III, s. 359-360, fol. 757; t. IV, s. 89, fol. 184; t. V, s. 7, fol. 5; t. V, s. 134, fol. 253.

84 Por. W. Kaczorowski, Sejm konwokacyjny i elekcyjny, s. 118-119; G. Lengnich, op.cit., s. 53; W. Serczyk, Na dalekiej Ukrainie. Dzieje kozaczyzny do 1648 roku, Kraków 1984, s. 308-310.

85 „[...] ieśliby woysko Rzeczyposp: Posły od siebie w iakiey potrzebie, na Ziazd Elekcyi przysłać chciało: tedy im to wolno będzie, byle tylko bez pocztów, we dwudziestu osób, y czeladź w to rachując, przyieżdżali”, VL t. III, s. 350, fol. 734; t. IV, s. 81, fol. 163; s. 490, fol. 1041; t. V, s. 118 , fol. 126. Widać tu ciekawy zabieg ograniczenia liczebności nie względem samych towarzyszy, ale także czeladzi. 
Ostatnią sprawą, którą chcielibyśmy poruszyć, jest kwestia partycypacji w akcie elekcyjnym cudzoziemców ${ }^{86}$. Powszechne, niewątpliwie słuszne, konstatacje literatury przedmiotu wskazujące na bujny rozwój ksenofobii w Rzeczypospolitej, zwłaszcza od 2. poł. XVII w., zdają się korespondować z zakazem udziału obcokrajowców w akcie elekcyjnym. Warto jednakże zaznaczyć, że sprawa wcale nie jest tak klarowna, a motywacje szlachty tak irracjonalne, jak mogłoby się wydawać na pierwszy rzut oka. Po pierwsze, niechęć szlachty do czynnej partycypacji cudzoziemców (szczególnie tych pozostających na usługach kandydatów do korony) w obradach elekcyjnych nie była uzasadniana nienawiścią do nich, lecz względami pragmatycznymi. Otóż swobodne poruszanie się obcokrajowców po terenie zjazdu stwarzało możliwość niekontrolowanej agitacji na rzecz cudzoziemskich kandydatów, często o znamionach korupcyjnych ${ }^{87}$. Szczególnie jaskrawo dało się to odczuć w omawianym przez nas okresie na elekcji 1587 r., kiedy to posłowie cudzoziemscy spotykali się na nieformalnych kolokwiach z głównymi aktorami polskiej sceny politycznej, a ze względu na trudny i skomplikowany konflikt dzielący pole elekcyjne na dwa oddzielne koła rycerskie niemożliwe było wyznaczenie im właściwych audiencji oficjalnych ${ }^{88}$. Odrębną sprawą było oczywiście zjawisko szpiegostwa. Wiemy dziś, że nawet tak odległe od Rzeczypospolitej państwa jak Imperium Ottomańskie czy Królestwo Anglii otrzymywały szczegółowe raporty od swoich agentów o przebiegu sejmu i samej elek-

86 Przepisy Aktu konfederacji generalnej i Porzadku elekcyjnego o zakazie przybywania na elekcję $z$ działami i cudzoziemcami już cytowaliśmy, por. przyp. 15.

87 O powszechności korupcji i to zarówno w postaci ewidentnych łapówek pieniężnych (zarówno wobec magnatów, jak i drobnej szlachty), drobnych przysług czy prezentów (np. zaproszeń na wieczerzę ubogich elektorów) świadzonych na rzecz elektorów przez agentów kandydatów zagranicznych wspominaliśmy już na łamach niniejszego szkicu (por. przyp. 44). Pisze się o tym problemie dość powszechnie w literaturze przedmiotu. Warto tu wymienić ostatnio wydaną, znakomitą monografię poświęconą zakulisowej działalności agentów francuskich w okresie elekcji 1697 r., pióra A. Skrzypietz, op.cit., passim.

88 Szczególnie dużo kulis nieformalnych negocjacji odsłania R. Heidenstein, op.cit., zwłaszcza s. 227-231. 
cji ${ }^{89}$. Inną kwestią, pomijaną w zasadzie w literaturze, a niezwykle istotną, były dwa specyficzne wyłączenie spod zakazu partycypacji cudzoziemców w sejmie elekcyjnym. Dotyczyły one cudzoziemców, których obecność w czasie zjazdu została zgłoszona marszałkowi wielkiemu koronnemu. Uzasadnieniem mógł być fakt, że cudzoziemcy ci:

1) przybyli jako obserwatorzy i nie mieli celów politycznych ani wywiadowczych (temu zawdzięczamy relacje obcokrajowców z elekcji np. autorstwa W. Beauplana) ${ }^{90}$,

2) cudzoziemców w pocztach szlacheckich (zwłaszcza masztalerzy $)^{91}$.

Informacja o cudzoziemcach przekazywana urzędowi marszałkowskiemu musiała być dość szczegółowa - żądano wskazywania celu oraz planów obcokrajowców, co do sposobu spędzania czasu w okresie zjazdu. Jeden $z$ przepisów zawierał wyraźną obawę przed działalnością szpiegów, którzy, udając np. handlarzy, podróżowaliby po terenie zjazdu, tworząc raporty dla swoich mocodawców ${ }^{92}$. Na cudzoziemców lekceważących wymóg zgłoszenia się patrzono

89 O raportach tureckich, które docierały do sułtana z 3-6-tygodniowym opóźnieniem (!) wspomina J.A. Chrościcki, op.cit., s. 188. O relacjach z elekcji wspomina T. Chynczewska-Hennel, Rzeczpospolita XVII wieku w oczach cudzoziemców, Wrocław-Warszawa-Kraków 1993, s. 126-129.

90 Niezwykle interesującą, choć nieprecyzyjną, bo poznaną pobieżnie z obserwacji, zniekształcanych do pewnego stopnia opiniami znajomych senatorów, relację Beauplana zawiera bezcenne wydawnictwo źródłowe zredagowane i przygotowane do druku przez prof. Z. Wójcika, por. W. Beauplan, op.cit., s. 161-165.

91 „Także ieśli kto nie do woienney potrzeby, alem propter domesticum ministerium cudzoziemca iednego lub kilku przy sobie chowa; luboby też cudzoziemiec który dla patrzenia się, y widzenia tegoż ziazdu, pacatus przyiechał; ten do teraźnieyszego artykułu pociągany bydź nie ma”, VL, t. III, s. 358, fol. 754; t. IV, s. 88, fol. 181; t. V, s. 5, fol. 2; s. 133, fol. 250.

92 „Z cudzoziemców aby żaden w Kole Rzpltey gdzie publica negotia odprawować się będą nie ważył się bywać, także y do miasta, y stanowisk, wieżdżać y chodzić, pod pretextem handlów, albo towarów iakich, aż za wiadomością Ichmciów PP. Marszałków oboyga narodów”, VL t. III, s. 360, fol. 757; t. IV, s. 89, fol. 184; t. V, s. 7, fol. 5; t. V, s. 134, fol. 254. 
z dużym niepokojem ${ }^{93}$. Zabezpieczano się jednak przed tego typu praktykami wprowadzaniem do przepisów porządkowych ciekawej regulacji, na mocy której nałożono na wynajmujących lokale obowiązek zgłoszenia swoich cudzoziemskich lokatorów marszałkowi pod groźbą kary ${ }^{94}$. Warte podkreślenia jest przy tym sformułowanie legalnej definicji „niecudzoziemca”, która wykazuje, że wiążący w ocenie nie był ani czynnik etniczny, ani kulturowy, ani językowy, tylko formalnoprawny, związany $z$ kategorią osiadłości w jednostce terytorialnej zależnej politycznie lub przyłączonej do Rzeczypospolitej ${ }^{95}$.

93 Na sejmie elekcyjnym 1587 r. kilka dni obrad zabrała sprawa tajemniczego Niemca, który został ujęty nie na terenie zjazdu elekcyjnego, lecz przed jego rozpoczęciem, na terenie Litwy, a który wioząc korespondencje między carem i cesarzem, czynił to potajemnie, przy czym nie potrafił się wylegitymować żadnymi pełnomocnictwami. W ocenie posłów koła poselskiego jedynym zagrożeniem było wożenie listów bez wiedzy i zgody Rzeczypospolitej, co rodziło podejrzenia co do swoistego „drugiego dna” całej misji; nie stanowił problemów sam fakt przebywania przezeń z misją dyplomatyczną państw ościennych w polskich granicach, por. O elekcyi królewicza, [w:] Dyaryusze, wyd. A. Sokołowski, s. 73-75. Ciekawe, że ów Niemiec łamał zwyczajową normę porządku w czasie bezkrólewia, według której posłowie cudzoziemscy, którzy w momencie dowiedzenia się o śmierci króla jeszcze nie przekroczyli granicy, powinni się byli na niej zatrzymać, a ci, którzy już ją przekroczyli, a nie dotarli do celu swej misji, winni byli zatrzymać się w miejscu. Kontynuować swą podróż mogli dopiero po pisemnym zawiadomieniu prymasa i uzyskaniu zgody na przemieszczanie się po Rzeczypospolitej, por. G. Lengnich, op.cit., s. 33.

94 [O cudzoziemcach] „gospodarze dawać znać powinni Ichmć PP. Marszałkom, sub poena arbitraria civili", VL t. III, s. 360, fol. 757; t. IV, s. 89, fol. 184; t. V, s. 7, fol. 5; t. V, s. 134, fol. 254.

95 „Za cudzoziemców nie maią bydź rozumiani terrignae Państw do Korony y W.X. L. Inkorporowanych; luboby ięzykiem y habitem od narodu naszego różni byli”, VL t. III, s. 358, fol. 754; t. IV, s. 88, fol. 181; t. V, s. 5, fol. 2; t. V, s. 133, fol. 250. Więcej informacji o szlacheckim pojmowaniu „obywatelstwa”, szczególnie o znaczeniu terminów indygena i terrigna odnajdzie Czytelnik w klasycznej pracy S. Grodziskiego, Obywatelstwo w szlacheckiej Rzeczypospolitej, Kraków 1963, s. 65-125. 


\section{Zakończenie}

Zdajemy sobie w pełni sprawę, że szkic niniejszy nie jest wystarczającą odpowiedzią na niedobory badań w zakresie skomplikowanych problemów organizacyjnych i porządkowych, z którymi musiała się borykać elita polityczna Rzeczypospolitej w procesie przygotowania zjazdów elekcyjnych. Naszej pracy przyświecała raczej idea uporządkowania pod kątem historyczno-prawnym dotychczasowych ustaleń nauki, $z$ wykorzystaniem ogólnodostępnych, drukowanych źródeł, zwłaszcza materiału normatywnego. Za szczególnie istotne uważamy zaproponowane na początku artykułu klasyfikacje elekcyjnych przepisów porządkowych, których brakowało, naszym zdaniem, w dotychczasowych analizach literatury przedmiotu. Ponadto staraliśmy się zwrócić uwagę na regulacje proceduralne stosowane $\mathrm{w}$ celu zapewnienia bezpiecznego dla uczestników i sprawnego $z$ prakseologicznego punktu widzenia przebiegu zjazdu.

Na koniec niniejszych rozważań pragniemy wskazać na problemy i zagadnienia związane $z$ porządkiem i bezpieczeństwem zjazdów elekcyjnych, których opracowanie jest naszym zdaniem nieodzowne dla pełnego zrozumienia fenomenu tych unikatowych zgromadzeń parlamentarnych i ich kulminacyjnych punktów - wyborów króla przez szlacheckich obywateli Rzeczypospolitej w systemie viritim. Po pierwsze, należy pracować nad dokonywaniem głębszej analizy treści przepisów porządkowych i ich wykładni na podstawie źródeł czy to formalnych, czy nieformalnych. $Z$ całą pewnością pozwoliłoby to ocenić skalę naruszeń omawianych regulacji i ich wymiar bardziej praktyczny. Po drugie, dojmująco brakuje w literaturze analiz, których przedmiotem byłaby skuteczność ochrony w przepisach porządkowych, roztaczanej nad mieszczanami Warszawy i okolic. Wielotysięczne, szlacheckie zjazdy elekcyjne w znacznie większym stopniu niż zwykłe sejmy musiały wpływać na funkcjonowanie stolicy państwa i pobliskich miejscowości. Z jednej strony, były one niewątpliwie szansą na wzrost inwestycji i intensyfikację handlu (także dzięki tymczasowej przeprawie mostowej). $Z$ drugiej wszelako strony, niosły za sobą zagrożenia związane zarówno ze wzrostem przestępczości (łączącym się nierozerwalnie ze spadkiem poczucia 
bezpieczeństwa, a także niszczeniem i kradzieżami mienia na pokaźną skalę), jak też z uciążliwymi obowiązkami kwaterunkowymi. Warto przy tym zanalizować, jeśli to w ogóle możliwe na podstawie zachowanych źródeł, jak na handel wpływało ustalanie odgórnych taks na towary i czy nie prowadzono przypadkiem handlu nieoficjalnego, na zasadach rynkowych w swoistym „drugim obiegu”, szczególnie że w wyniku niedoborów aprowizacyjnych ceny winny gwałtownie wzrastać, co rodziłoby olbrzymią opłacalność tego typu praktyk. Po trzecie, niezwykle ważkim zagadnieniem są sprawy na pierwszy rzut oka prozaiczne, ale mogące rzucić sporo światła na życie codzienne uczestników zjazdu, takie jak organizacyjne problemy $z$ załatwianiem potrzeb fizjologicznych $w$ trakcie wielogodzinnych obrad, albo zagadnienie prostytucji w realiach skomasowania tłumu mężczyzn na niewielkim stosunkowo obszarze, $z$ dala od naturalnego środowiska rodzinnego i towarzyskiego. Po czwarte, należałoby zanalizować elekcyjne przepisy porządkowe w kontekście ogólnego rozwoju ówczesnego prawa koronnego i to zarówno karnego, jak i administracyjnego. Jak wiadomo, polskie prawo tamtego czasu nie doczekało się kodyfikacji, a zatem omawiane przez nas regulacje stanowiły $\mathrm{w}$ istocie jedne $\mathrm{z}$ naprawdę niewielu pisanych źródeł prawa w tych sferach. Osadzenie elekcyjnych przepisów porządkowych w szerokim kontekście prawa sądowego oraz organizacji administracji Polski szlacheckiej, opierających się głównie na normach prawa zwyczajowego, mogłoby dać nową, szerszą perspektywę $\mathrm{w}$ pracach badawczych zarówno w ujęciach szczególnych, jak i syntetycznych.

Na zakończenie raz jeszcze wypada podkreślić potrzebę intensyfikacji badań nad zjazdami elekcyjnymi, będącymi nie tylko wydarzeniami o kluczowym znaczeniu dla dziejów polityki i ustroju Rzeczypospolitej, ale także zjawiskami unikatowymi w perspektywie dziejów Europy. Niezależnie od oceny, czy burzliwe zgromadzenia tłumów szlachty miały jakikolwiek sens, a nawet przy antycypacji, że były wypaczeniem idei demokratycznej i eskapistyczną aberracją ideologiczną, która otworzyła drogę ingerencji państw obcych w wewnętrzne sprawy Rzeczypospolitej, a w konsekwencji rozbiorom, należy podkreślić, iż doświadczenie wolnych elekcji wpisuje się w szeroki nurt europejskiej tradycji dopuszczania do partycy- 
pacji w desygnowaniu władz publicznych szerokich mas społeczeństwa. Ta specyficzna polska konstrukcja ukazuje nam przecież wszystkie zalety współczesnych demokracji: poczucie wolności i odpowiedzialności za losy państwa oraz wzrost obywatelskiej świadomości, ale także wady tego systemu: znaczącą dozę ignorancji wyborców na temat stanu spraw państwa, korupcjogenność i podatność na manipulacje propagandowe. Badania nad wolnymi elekcjami stanowić zatem powinny jedno $z$ priorytetowych zadań polskiej historiografii, szczególnie w kontekście wkładu i korespondencji z dokonaniami nauki europejskiej.

\section{SUMMARY}

\section{The provisions about the security and order on the election conventions in the years 1587-1674}

Present article concerns the provisions about the security and order during the election of the king in Both Nations Commonwealth, which were designed to ensure the safe and lawful carrying out election conventions. The purpose of these provisions was guaranteeing: proper organization of the meeting of Legislature (known as The Circle of Knights), correct adoption of foreign envoys and lawful conduct of monarch election. These regulations were prepared to fight with the criminal offences and assurance the legal instruments to cope with problems concerning with functioning security services, building infrastructural facilities and supplying food. The author points at heterogenic nature of provisions of the security and order during the election of the polish kings, which included both procedural as well as substantive rules. Furthermore, substantive rules were related not merely with the criminal provisions, but also the others, similar to present-day regulations, which secure the mass events. The author tries to present the process of preparation and implementation of the provisions about the security and order during the election of the polish kings as one of the main tasks in the process of organization of the election conventions.

Key-words: Both Nations Commonwealth, Polish Sejm, free elections, election conventions, provisions about security and order during elections of polish kings, hood courts 